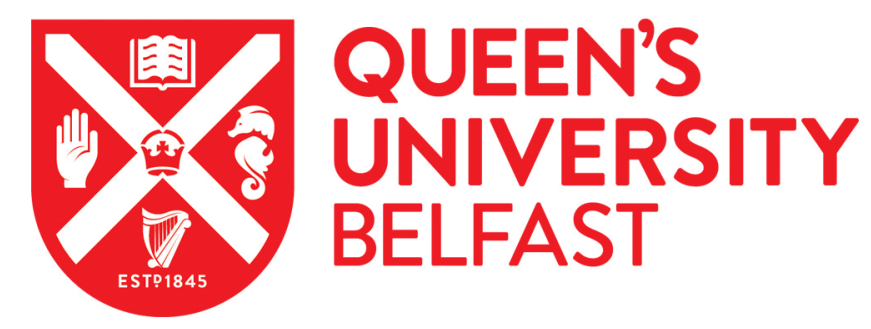

\title{
Peer social network processes and adolescent health behaviors: a systematic review
}

Montgomery, S. C., Donnelly, M., Bhatnagar, P., Carlin, A., Kee, F., \& Hunter, R. F. (2020). Peer social network processes and adolescent health behaviors: a systematic review. Preventive Medicine, 130, [105900]. https://doi.org/10.1016/j.ypmed.2019.105900

Published in:

Preventive Medicine

Document Version:

Peer reviewed version

Queen's University Belfast - Research Portal:

Link to publication record in Queen's University Belfast Research Portal

Publisher rights

(C) 2019 Elsevier Inc.

This manuscript version is made available under the CC-BY-NC-ND 4.0 license http://creativecommons.org/licenses/by-nc-nd/4.0/,which permits distribution and reproduction for non-commercial purposes, provided the author and source are cited.

\section{General rights}

Copyright for the publications made accessible via the Queen's University Belfast Research Portal is retained by the author(s) and / or other copyright owners and it is a condition of accessing these publications that users recognise and abide by the legal requirements associated with these rights.

Take down policy

The Research Portal is Queen's institutional repository that provides access to Queen's research output. Every effort has been made to ensure that content in the Research Portal does not infringe any person's rights, or applicable UK laws. If you discover content in the Research Portal that you believe breaches copyright or violates any law, please contact openaccess@qub.ac.uk. 
Title: Peer social network processes and adolescent health behaviors: a systematic review

Authors:

Shannon C. Montgomery ${ }^{\mathrm{a}^{*}}$, Michael Donnelly ${ }^{\mathrm{a}}$, Prachi Bhatnagar ${ }^{\mathrm{b}}$, Angela Carlin ${ }^{\mathrm{c}}$, Frank $\mathrm{Kee}^{\mathrm{a}}$, Ruth F. Hunter ${ }^{{ }^{*}}$

${ }^{a} U K C R C$ Centre of Excellence for Public Health (Northern Ireland)/Centre for Public Health, School of Medicine, Dentistry and Biomedical Sciences, Queen's University Belfast, Clinical Sciences Block B, Royal Victoria Hospital, Belfast, Northern Ireland, UK ${ }^{b}$ Centre on Population Approaches for Non-Communicable Disease Prevention, Nuffield department of Population Health, University of Oxford, Old Road Campus, OX3 7LF 'Sport and Exercise Sciences Research Institute, Ulster University, Northern Ireland, UK *Joint corresponding authors

Email addresses: smontgomery18@qub.ac.uk (S. C. Montgomery);

Michael.donnelly@qub.ac.uk (M. Donnelly); prachi.bhatnagar@ndph.ox.ac.uk (P. Bhatnagar); a.carlin1@ulster.ac.uk (A.Carlin); f.kee@qub.ac.uk (F. Kee) ruth.hunter@qub.ac.uk (R.F. Hunter)

Keywords: adolescents; health behaviors; health behavior change; social networks; systematic review.

Conflicts of interest: none

Funding body: SM was funded by a PhD studentship by the UKCRC Centre of Excellence for Public Health (Northern Ireland). Funding reference: MR/K023241/1 and 1630370 and MC_CF23241. RH was funded by a Career Development Fellowship from the National Institute for Health Research (NIHR) (CDF-2014-07-020). 


\begin{abstract}
Research has highlighted the importance of peers for determining health behaviors in adolescents, yet these behaviors have typically been investigated in isolation. We need to understand common network processes operating across health behaviors collectively, in order to discern how social network processes impact health behaviors. Thus, this systematic review of studies investigated adolescent peer social networks and health behaviors. A search of six databases (CINAHL, Education Resources Information Centre, Embase, International Bibliography of the Social Sciences, Medline and PsycINFO) identified 55 eligible studies. The mean age of the participants was 15.1 years (range $13-18 ; 51.1 \%$ female). Study samples ranged from 143 to 20,745 participants. Studies investigated drinking (31\%), smoking (22\%), both drinking and smoking (13\%) substance use (18\%), physical activity $(9 \%)$ and diet or weight management (7\%). Study design was largely longitudinal $(n=41$, $73 \%)$ and cross-sectional $(n=14,25 \%)$. All studies were set in school and all but one study focused on school-based friendship networks. The Newcastle-Ottawa scale was used to assess risk of bias: studies were assessed as good (51\%), fair (16\%) or poor (33\%). The synthesis of results revolved around two network behavior patterns: 1) health behavior similarity within a social network, driven by homophilic social selection and/or social influence, and 2) popularity: health behavior engagement in relation to changes in social status; or network popularity predicting health behaviors. Adolescents in denser networks had statistically significant lower levels of harmful behavior $(n=2 / 2,100 \%)$. Findings suggest that social network processes are important factors in adolescent health behaviors.
\end{abstract}

\title{
Word count: 249
}




\section{Introduction}

Adoption and engagement in health behaviors is seldom an individual decision, as individuals are influenced by the people with whom they spend time (i.e. the social networks within which they are embedded, with ties connecting them to other individuals through social relationships, facilitating diffusion of behavior and information ${ }^{1}$ ). As an adolescent matures, peers (individuals who are at a similar life stage ${ }^{2}$ ) become increasingly important in determining behavior, particularly given the increase in the amount of extra-curricular time spent socializing ${ }^{3}$ coupled with increasing independence from family ${ }^{4}$. Additionally, adolescents become increasingly motivated to fit into social group identities and to adopt the normative behaviors of their peers ${ }^{5}$.

Previous systematic reviews found significant relationships between health behaviors of adolescents and their peers ${ }^{6-12}$. Peers and friendship groups played an important role in shaping adolescent physical activity (PA) behavior ( $\mathrm{n}=7$ studies, aged 6-18 years $)^{7}$. A further review concluded friends' PA behavior had significant influence on adolescents' PA behavior, and adolescents' PA behaviors were associated with friends' PA behaviors, alongside encouragement, support and engagement with friends in PA (significant positive results in $n=40 / 81$ studies, aged $<19$ years $)^{8}$. Similarly, a third review concluded that friends' PA behavior had a significant influence on individuals' PA behavior and peer networks exerted greater influence on boys' PA behavior than girls' PA behavior ( $\mathrm{n}=13$ studies, aged 6-18 years $)^{9}$. Furthermore, Fletcher et al found significant similarities between school friends' eating behaviors and bodyweight ( $\mathrm{n}=10$ studies, aged 11-18 years) though definitive conclusions regarding network processes could not be ascertained due to inconsistencies between study findings ${ }^{6}$. Zhang et al found similar evidence $(n=7 / 8$ studies focused on adolescents' friendship networks) and concluded that friends were similar in weight status and related behaviors, and that friendship networks and weight outcomes or behaviors were interdependent ${ }^{10}$. This review also provided evidence for specific network effects. For example, friends' body mass index (BMI) predicted changes in adolescent's BMI and selection effects contributed to similarities in weight ${ }^{10}$. A review on smoking behavior demonstrated the importance of network structure ${ }^{11}$. In particular, adolescents who were identified as 'isolates' (i.e. individuals with no friends) were more likely to smoke compared to others in the network ( $\mathrm{n}=10$ studies $)^{11}$. Furthermore, adolescents who affiliated with 
alcohol drinking peers had a significantly higher risk of individual alcohol use $(n=22$ studies $)^{12}$.

Previous systematic reviews identified homophilic social selection (i.e. selection of friends on the basis of similarities in behavior, attitudes or demographic characteristics ${ }^{13-15}$ ) and social influence (i.e. influence from peers to change behavior due to spending time together, shared activities, peer norms and modelling of habits ${ }^{16}$ ) as network processes that are common across health behaviours. Alongside these, there is a need to synthesize the importance of popularity (i.e. receiving a high number of friendship nominations ${ }^{17,18}$ ) across health behaviours. There is mixed evidence regarding the relationship between popularity and health behaviors, particularly for smoking. For example, a study found popular adolescents (aged 11-12 years) were more likely to engage in smoking behavior compared to their less popular peers ${ }^{18}$. In contrast, other research suggests that smoking may be associated with social isolation or having fewer friends (aged 11-19 years) ${ }^{19}$, and popular individuals generally may be more influential than their less popular peers ${ }^{20}$. Thus, there is a need to investigate the role of popularity across a range of health behaviors and improve understanding about the implications of social status in relation to determining health behavior choices, which has implications for broader network diffusion. For example, the 'majority illusion paradox' suggests that popular nodes have greater influence and power to skew the observations of others within the network ${ }^{21}$.

The network processes identified above may be synthesized as two network-behavior patterns (which provide understanding about individuals' behavior within a social network) and four underlying mechanisms. Firstly, the pattern of health behavior similarity among socially connected youth (network autocorrelation) may be driven by (a) similarity/homophily-based social selection and/or (b) social influence. Secondly, associations between health behaviors and network popularity may be driven by (a) tendencies to select network partners who exhibit a given health behavior (i.e. engagement in the given behavior leads to changes in popularity), and/or (b) network popularity predicting behavior change (i.e. popular youth are more likely to adopt or avoid a behavior).

Whilst the impact of peer networks upon individual health behaviors has been widely researched, this research has focused on only single behaviors ${ }^{6-11}$. Health behaviors tend to cluster together ${ }^{22,23}$, yet we lack a clear understanding about how network processes influence 
these behaviors collectively ${ }^{24}$. Gateway theories suggest engagement in one form of healthharming behavior leads to opportunities for engagement in other risky behaviors ${ }^{25}$. Furthermore, Jessor's 'problem behavior theory' ${ }^{26}$ suggests that early adolescent engagement in 'problem behaviors' is an attempt to "demonstrate maturity, independence and repudiating conventionality" 23 . In particular, previous evidence supports clustering of health-harming smoking and drinking behaviors ${ }^{27}$. Research indicates clustering occurs at both ends of the spectrum; individuals may engage in no health harming behaviors (or health-enhancing behaviors), or a high level of health-harming behaviors ${ }^{22}$ (or health-enhancing behaviors).

Given the complex relationships between individual health behaviors ${ }^{28}$ better understanding about social network processes and how they relate to health behaviors may be useful to inform design and implementation of future health behavior change interventions with adolescents. Social networks may facilitate or impede health behavior change through a number of mechanisms ${ }^{24}$ (i.e. through modelling peer behavior ${ }^{29}$, or establishment of peer social norms ${ }^{30}$ ). Understanding the social environments that an intervention is delivered in can allow for tailoring, thereby potentially increasing the effectiveness ${ }^{24}$. Social networks do not act in isolation and impact behavior across multiple levels of the social environment within a complex system of influences ${ }^{31}$. Berkman's conceptual model provides understanding about how social networks are conditioned by social-structural conditions, and provide opportunities for behavioral mechanisms to impact health through a series of pathways $^{32}$.

The role of social network processes on adolescent health behaviors requires further exploration in order to advance our understanding about how social network processes operate. Previous reviews focused on dyadic level approaches, involving, for example, the incorporation of peers as 'buddies', with the aim of encouraging intervention adoption ${ }^{33}$. Clearly, there is a recognized need now for a review that focuses on studies of social network processes that move beyond the dyad-level ${ }^{6,10}$. The explicit use of social network data to map the structure of social connections among groups of people and distinguish social network processes from general peer support and social support has been studied previously ${ }^{34,35}$ typically focusing on individuals' perceptions about social phenomena (i.e. social norms) ${ }^{36-38}$ or on dyads ${ }^{39}$. The nature and extent to which the myriad of social network processes impact on various health behaviors during adolescence remains unknown. The present study addressed this gap by conducting a systematic review of studies that investigated the 
association between peer network processes and health behaviors in adolescents (aged 13-18 years), particularly in relation to the extent to which specific network processes were observed across common adolescent health behaviors.

\section{Methods}

The PRISMA guideline for systematic reviews was followed ${ }^{40}$.

\subsection{Systematic search}

Searches were conducted for studies published up to October 2018 on CINAHL, Education Resources Information Centre (ERIC), Embase, International Bibliography of the Social Sciences (IBSS), Medline and PsycINFO. Keywords relating to social networks, health behaviors and adolescence were searched (see Appendix A).

\subsection{Eligibility criteria}

Studies were selected based on the pre-defined eligibility criteria outlined in Table 1.

\subsection{Study selection}

After removing duplicates, titles and abstracts were screened in accordance with the eligibility criteria. The relevant full texts were screened by two independent researchers (SM, RH) and discrepancies resolved by face-to-face discussion. Reference lists of included studies were hand-searched for additional eligible articles.

\subsection{Data extraction}

Data were extracted from included studies using a pre-defined form by one researcher (SM) and independently cross-checked by two other members of the research team (PB, AC). Extracted data included study details; social network and health behavior measures; analysis method and results.

\subsection{Risk of bias and study quality}

The Newcastle-Ottawa Scale (NOS) for cross-sectional studies was used to assess the risk of $\operatorname{bias}^{41}$. Although included studies varied in their study design, many studies used a crosssectional measure of the network or measured the health behavior at only one time-point. 
Therefore, to allow for consistent assessment of bias across the range of studies, the NOS for cross-sectional studies was used. The studies were assessed for risk of bias by two independent researchers (SM, RH) and discrepancies dealt with through face-to-face discussions. We converted the risk of bias categories to study quality categories defined by the Agency for Health Research and Quality (AHRQ) (good, fair and poor quality) as reported in previous literature ${ }^{42}$. Findings from the risk of bias and study quality assessment did not determine the inclusivity of studies.

\subsection{Evidence synthesis}

The results from eligible studies are presented as two network-behavior patterns (i.e. clusters of behavior within a social network) with underlying mechanisms: (1) health behavior similarity which could be driven by (a) homophilic social selection; and/or (b) social influence; and (2) the association between popularity and health behaviors, which could be driven by (a) engagement in behavior(s) leading to changes in adolescent's social status and (b) network popularity predicting health behavior(s). An additional category was included for 'other' processes. These processes were presented in relation to each health behavior. A qualitative narrative synthesis was conducted. The methodological heterogeneity of the studies precluded conducting a meta-analysis.

\section{Results}

A total of 8,779 articles were identified from the search; 225 articles were identified for full text screening, and 46 articles included. Nine articles were identified from manual searching of reference lists, resulting in a total of 55 included studies. Figure 1 provides details of the process.

\subsection{Study characteristics}

Characteristics from each study are summarized in results Tables 2-7. Studies investigated alcohol drinking $(n=17,31 \%)$, cigarette smoking $(n=12,22 \%)$, both drinking and smoking combined $(n=7,13 \%)$, substance use $(n=10,18 \%), P A(n=5,9 \%)$ and dietary/weight-related behaviors $(n=4,7 \%)$. The mean age of the participants was 15.1 years (range $13-18)$ and $51.1 \%$ were female. Study populations ranged from 143 to 20,745 participants. The majority $(\mathrm{n}=40,73 \%)$ of the studies were based in The United States of America (USA), of which $70 \%(n=28 / 40)$ were from the National Longitudinal Study of Adolescent to Adult Health 
(Add Health) study, a longitudinal, nationally representative sample of adolescents in grades 7-12 during the 1994-5 school year, which followed adolescents into adulthood and collected data on a range of social, economic, environmental, behavioral and biological data ${ }^{43}$. The remaining studies were set in the United Kingdom (UK) $(n=2,4 \%)$, Australia $(n=4,7 \%)$, Europe $(n=6,11 \%)$, Canada $(n=1,2 \%)$ and Asia $(n=2,4 \%)$.

All studies used name generation techniques to collect social network data ${ }^{44}$ (Appendix B, Tables B1-6). With the exception of one study ${ }^{45}$, the studies measured and focused on friendship networks. Additional network measures included peer-perceived and relational aggression networks ${ }^{45}$; romantic dyad networks ${ }^{46,47}$; peer leader networks ${ }^{48}$; 'group project' networks ${ }^{48}$ and best friend dyads ${ }^{39,49,50}$. Three studies also measured popularity ${ }^{45,51,52}$. Further detail regarding the social network questions, alongside demographic characteristics and study design can be found in Appendix B, Tables B1-6.

The following section is presented as an overview of the findings for health behavior similarity among socially connected youth (and associated mechanisms) and popularity and health behaviors (and associated mechanisms). Further detailed study findings are provided in Appendix C.

\subsection{Health behavior similarity among socially connected youth}

\subsubsection{Homophilic social selection}

Nine studies investigated homophilic social selection but not social influence ${ }^{47,52-59}$. One study controlled for social influence effects ${ }^{56}$. The health behaviors investigated were alcohol drinking $(n=3)^{52-54}$; cigarette smoking $(n=2)^{55,56}$; both drinking and smoking $(n=1)^{47} ;$ PA $(n=2)^{57,58}$ and dietary-related behaviors $(n=1)^{59}$ (Table 2). Five studies were crosssectional $^{52,55,57-59}$ and four were longitudinal ${ }^{47,53,54,56}$. Four studies were rated 'good quality'53-55,59; two 'fair quality' ${ }^{52,57}$ and three 'poor quality ${ }^{37,56,58}$. Overall, homophilic social selection was significantly and positively associated with health behavior(s) in 8/9 studies $^{47,52,53,55-59}$. 


\subsubsection{Social influence}

Fifteen studies investigated the association between social influence, but not homophilic social selection, and health behaviors ${ }^{39,48,49,60-71}$. Studies which reported only findings for the association of peer influence either did not report selection ${ }^{39,48,49,62-64,67-69,71}$ or controlled for selection, but did not explicitly report findings on the association between social selection and health behavior ${ }^{60,61,65,66,70}$. The health behaviors investigated were alcohol drinking $(n=5)^{49,66-69}$; cigarette smoking $(n=2)^{65,70}$; both drinking and smoking $(n=4)^{60-62,71}$; substance use $(n=2)^{48,63}$; PA $(n=1)^{39}$ and dietary-related behaviors $(n=1)^{64}$ (Table 3). Five studies were cross-sectional ${ }^{39,49,60,69,71}$ and 10 were longitudinal ${ }^{48,61-68,70}$. Ten studies were rated 'good quality ${ }^{48,60,64-71}$; two were rated 'fair quality'49,63 and three 'poor quality' 39,61,62. Overall, social influence was significantly associated with health behavior(s) in 14/15 studies ${ }^{39,48,49,60-}$ 63,65-71.

\subsubsection{Homophilic social selection and social influence}

Twenty-two longitudinal studies investigated both homophilic selection of friends on the basis of similarity in health behavior(s) and social influence leading adolescents to change their behaviors to become more similar to their friends' behaviors ${ }^{46,50,51,72-90}$. The health behaviors investigated were alcohol drinking $(n=5)^{46,80,84-86}$; cigarette smoking $(n=7)^{79,81,82,87-}$ ${ }^{90}$; both drinking and smoking $(\mathrm{n}=2)^{72,73}$; substance use $(\mathrm{n}=4)^{51,74-76}$; PA $(\mathrm{n}=2)^{77,78}$ and dietary/weight-related behaviors $(n=2)^{50,83}$ (Table 4). These included nine ' $g o o d$ quality'46,50,73,76,77,80,84,88,89 , three 'fair quality'51,78,81 and nine 'poor quality' $72,74,75,79,82,85-87,90$ studies. The majority of studies acknowledged the presence of both homophilic social selection and social influence processes, but did not disentangle the relative contribution of either process ${ }^{46,50,83,85,87,88,90,72-76,79,81,82}$. Seven studies used Stochastic Actor Oriented Models (SAOM) to attempt to disentangle the social processes ${ }^{51,77,78,80,84,86,89}$. Overall, significant associations were found for only homophilic social selection in one study investigating alcohol behavior ${ }^{84}$ and for only social influence in one study investigating low-nutrientenergy-dense (LNED) foods ${ }^{50}$. Both homophilic social selection and social influence were associated with health behavior(s) in 20 studies $^{46,51,80-83,85-90,72-79}$.

\subsection{Popularity and health behaviors}




\subsubsection{Popularity: engagement in health behavior(s) leading to changes in social status}

Thirteen studies investigated the association between popularity driven by engagement in behaviors, which resulted in a change in adolescents' popularity levels $\mathrm{s}^{50,54,91-}$

93,57,66,70,73,77,79,85,90. The health behaviors investigated were alcohol drinking $(n=6)^{54,66,85,91-93}$; cigarette smoking $(n=3)^{70,79,90}$; both drinking and smoking $(n=1)^{73}$; PA $(n=2)^{57,77}$ and dietaryrelated behaviors $(\mathrm{n}=1)^{50}$ (Table 5). Three studies were cross-sectional ${ }^{57,91,92}$ and ten studies were longitudinal $1^{50,54,66,70,73,77,79,85,90,93}$. Seven studies were rated 'good quality $50,54,66,70,73,77,91$, three 'fair quality' ${ }^{57,92,93}$ and three 'poor quality"79,85,90 . Overall, 11/13 studies found positive and significant associations between popularity and engagement in health behaviour(s) ${ }^{50,57,93,66,70,73,77,79,90-92}$.

\subsubsection{Popularity: network popularity predicting health behavior(s)}

Fifteen studies associated network popularity with predicting health behavior(s) 45,51,52,55,56,63,67,68,76,81,84,94-97. The health behaviors investigated were alcohol drinking $(n=5)^{45,52,67,68,84}$; cigarette smoking $(n=4)^{55,56,81,94}$ and substance use $(n=6)^{51,63,76,95-97}$ (Table 6). Four studies were cross-sectional $1^{52,55,95,96}$ and 11 studies were longitudinal $45,51,56,63,67,68,76,81,84,94,96,97$. Seven studies were rated 'good quality' $55,67,68,76,84,94,95$, three 'fair quality'51,63,81 and five 'poor quality'45,52,56,96,97. Overall, 13/15 studies found positive and significant associations for network popularity predicting health behavior(s) $)^{45,51,52,55,56,67,68,81,84,94-97}$.

\subsection{Other}

Studies which investigated the association between 'other' social network processes and health behaviors included two 'good quality' longitudinal studies which measured network density $^{67,98}$ (Table 7). One study using the Add Health data found adolescents in denser networks had lower levels of alcohol use ${ }^{67}$ and another American study found adolescents in denser networks had lower odds of smoking and marijuana use ${ }^{98}$. This study also found isolates were more likely to be smokers compared to group members ${ }^{98}$.

\subsection{Risk of bias and study quality}

Table 8 reports the risk of bias and study quality. The included studies averaged six stars out of 10 (range 2-8). Risk of bias was assessed on three main categories; selection, 
comparability and outcome. The adapted NOS used, with the sub-heading breakdown can be found in Appendix D. The heterogeneity of the statistical analysis methods used across the studies (i.e. exponential random graph modelling (ERGM), SAOM, regression models) made it difficult to assess the comparability, therefore no studies were excluded on the basis of their risk of bias, and bias was not considered when extracting data from studies and collating the evidence. The risk of bias categories were converted to study quality (good, fair and poor quality) as reported in previous literature ${ }^{42}$. Twenty-eight studies were 'good', nine were 'fair' and 18 were 'poor' quality. The findings highlighted a substantial proportion of poor quality evidence, particularly within the areas of smoking, substance use and PA.

\section{Discussion}

The results from this systematic review highlight a body of evidence supporting the importance of peer networks on adolescent health behaviors through social processes. There is limited evidence (due to a lack of studies) to support the presence of other network processes, with network density identified as important in two studies. Furthermore, the mixed study quality indicates the heterogeneity of the research methods utilized within the studies and calls for consistent methodology for conducting and reporting of social network analysis studies.

\subsection{Health behavior similarity among socially connected youth}

This review provides support for homophilic social selection and social influence as important social processes associated with health behaviors, however the results highlighted mixed study quality. Generally, the studies investigated school-based friendship networks and indicated that adolescents selected friends who had similar health behaviors to themselves. Selection of friends on the basis of similar health behaviors can protect individuals from developing unhealthy behaviors (i.e. for adolescents who abstain from health-harming behaviors or engage in health-enhancing behaviors, selection of friends who exhibit similar behaviors may lead to reinforcements of such healthy habits.) In contrast, selection of friends on the basis of similar health-harming behaviors may be detrimental, given greater exposure to the behavior ${ }^{29}$. Findings from a previous systematic review determined that adolescents who have friends who exhibit 'risky' behaviors are at increased risk of engaging in the behavior $^{99}$. Results indicated that adolescents were influenced by their peers to change their health behavior or to become more similar to their friends' behavior. Research has shown that 
adolescents desire to conform to social norms, and fit in with their peers to reduce social ostracism $^{100}$ and as a result, they are susceptible to peers' behavioral choices ${ }^{48}$. This is supportive of previous research which found that influence, whether positive or negative, was associated with friends' behaviors ${ }^{29}$. Furthermore, this review highlighted that influence may be present across all types of peer relationship ties (i.e. friends or romantic partners). However, due to lack of research outside of (mainly school-based) friendship networks, it is not possible to assess the extent to which different types of relationship ties have different influential power.

\subsection{Network popularity}

Popularity was identified as an important process in adolescent health behavior. The association between popularity and health behaviors could be driven by increases in social status as a result of (dis)engaging in the behavior(s), or changes in the behavior as a result of social status. The results indicated that popularity was associated with increasing health behavior levels, particularly health-harming behaviors. The findings also suggested that more popular adolescents might do more $\mathrm{PA}^{57,77}$. Further research is required to determine causality, as it is not possible to determine if being popular increased health behavior engagement or if engaging in the behaviors increased popularity. There was some indication that drinking only increased popularity levels when it was below a certain level (i.e. the class average ${ }^{91}$ ), suggesting that adolescents may engage in some health-harming behaviors to raise their social profile. However, a lack of evidence in this area warrants further research.

\subsection{Other social network processes}

This review identified a lack of research outside of the commonly investigated network processes of homophilic social selection, social influence and popularity. Whilst the evidence base was limited, findings from two studies indicated a positive association between individuals in denser networks and lower levels of harmful health behaviors. Previous research has indicated density, and other social network factors, may be an important moderator of diffusion using opinion leaders in social network interventions ${ }^{24}$. Furthermore, there is indication that network properties (i.e. density, reciprocity) may provide opportunities for behavioral mechanisms that impact health through different pathways (i.e. social engagement may impact alcohol drinking through health behavioral pathways $)^{101}$. Whilst this suggests social network factors may have important implications for adolescent health 
behaviors, there is a need for further research to investigate how these social network factors may best be utilized within intervention design.

\subsection{Implications for health behavior change interventions}

Social network interventions have been identified as effective in health behavior change ${ }^{24,102}$. However, evidence has shown network components are generally underutilized within health behavior interventions ${ }^{103,104}$. Many social network interventions within health behavior research have focused on individual approaches ${ }^{105,106}$ (i.e. identifying individuals based on a network property to promote positive behavior change) ${ }^{107}$. For example, ASSIST (A Stop Smoking In Schools Trial), is based on the diffusion of innovations theory which utilizes influential pupils to cascade anti-smoking information and has been shown to cost-effectively lead to a reduction in adolescent smoking prevalence ${ }^{108,109}$. The ASSIST framework has also been adopted in other areas of adolescent health behaviour research, including $\mathrm{PA}^{110}$, healthy eating for obesity prevention ${ }^{111}$, drug use prevention ${ }^{112}$ and sexual health ${ }^{113}$. This review has highlighted incorporation of social network processes within behavior change interventions may increase the effectiveness of such efforts. Furthermore, integration of these processes within intervention design may allow for other social network intervention approaches, such as segmentation, induction or alteration approaches ${ }^{107}$ to be utilized more effectively within intervention design.

\subsection{Directions for future research}

Previous research has identified clustering of health risk factors across multiple age groups ${ }^{22}$, including healthy behaviors ${ }^{114}$, and risk behaviors ${ }^{114-116}$. There is therefore an opportunity to investigate common network processes and clusters of behavior, given that this review has identified the presence of shared network processes at work across different health behaviors. A previous review investigating clustering of obesogenic behaviors in youth found cluster patterns were complex, and health-enhancing and health-harming behaviors can co-occur ${ }^{117}$. Research has also shown that clustering is affected by multiple sociodemographic factors including socioeconomic status, parental education, gender and age $\mathrm{e}^{117,118}$. There is a need to tailor interventions to specific populations, taking into account sociodemographic and socioeconomic differences ${ }^{118}$. Further research is required to investigate mechanisms of social networks impacting on health behavior clustering. In particular, this review highlighted a lack of evidence surrounding health-enhancing behaviors (i.e. PA and dietary behaviors). 
Investigation of association between social networks and these behaviors collectively may be useful for encouraging positive healthy behaviors in adolescents. Furthermore, there is a need to investigate distribution of health behaviors across social networks. This may have important implications for intervention design, as it would allow for tailoring of the social network intervention, by providing rationale for specific network strategies to encourage health-enhancing behavior change.

Furthermore, research is required outside of friendship networks, to identify other influencing factors, which may contribute to some individuals being more influenced by certain types of relationship ties. Social networks have been described as dynamic ${ }^{119}$ indicating that network ties are not static and network processes will not operate at a fixed rate. To the best of our knowledge, there is a relative lack of recent longitudinal studies spanning across multiple years. This review has identified studies which used longitudinal modelling (i.e. SAOM) were of higher quality and were able to identify dual processes such as both homophilic selection and influence processes impacting on health behaviors. There is a need for further longitudinal investigation of social network processes outside of the commonly investigated processes identified within this review, with clustering of health behaviors.

Study design by which dynamic social networks can be captured may benefit through the use of ecological momentary assessment (EMA), by which handheld devices (i.e. smartphone technology) capture real-time experiences within natural settings ${ }^{120}$. Such methods have been highlighted for the ability to capture change in behavior, such as $\mathrm{PA}^{121}$ and have been deemed successful in previous research ${ }^{122}$.

Some studies using data from Add Health showed inconsistent findings ${ }^{53,54,91}$. For example, two 'good quality' studies which investigated homophilic social selection found inconsistent findings for alcohol drinking. Positive and significant associations were found for homophilybased selection effects in one study ${ }^{53}$ but not a second study ${ }^{54}$. Whilst both studies used the same dataset, they differed in analytical sample size $\left(7,768^{53}\right.$ compared to $3,561^{54}$ participants) and analytical methodology (regression models ${ }^{53}$ compared to $\mathrm{SAOM}^{54}$ ). These findings highlight the need for a reporting framework in social networks research to better compare studies that use similar research methods. This framework would allow for consistent conducting and reporting of social network analyses, by detailing the specific social network measure, network boundary, analytical technique and other important 
methodological aspects which may contribute to heterogeneity of findings. Furthermore, it would be beneficial for researchers to document their power analysis (where possible) so that it is clear to the reader if the study is powered (or not) to detect expected effect sizes. There have since been advances in power analyses for social network models in recent years that researchers can now utilize which would enhance statistical reporting of studies ${ }^{123}$.

\subsection{Strengths and limitations}

To our knowledge, our review is the first to investigate the association between adolescent social networks and important health behaviors collectively, without focusing on a particular health behavior.

A limitation of the evidence base is that it is heavily influenced by one study, Add Health ${ }^{43}$. Forty of the included studies $(73 \%)$ were set in the USA, of which $70 \%(n=28 / 40)$ were from Add Health. Although Add Health was a representative sample of adolescents in USA, studies in this review used data collected from 1994-2002. Therefore, it is possible that rates of health behaviors may be different when compared to adolescents today. Furthermore, significant advances in digital social media have solidified social media platforms in everyday life $\mathrm{e}^{124}$ and much adolescent peer to peer interaction is communicated via these methods ${ }^{125}$. The way behaviors interact may be different today in the social media age. In particular, concerning evidence has indicated that peer influence effects for risk behaviors (i.e. smoking) may be more easily transmitted via online networks ${ }^{15}$. Whilst representative at the time, Add Health did not incorporate such social network measures.

Due to the heterogeneity of the research methods of the included studies, it was not possible to conduct a meta-analysis. Therefore, a limitation of this review is that we are unable to formally assess publication bias, with, for example an analysis of funnel plots or other methods. However, it highlights an inherent problem for assembling evidence from transdisciplinary research spanning both social network and traditional health research methods. For example, there are few studies of 'other' social network processes and health behaviors, however it is possible that they have been investigated in some earlier models but have been dropped from the final model in favor of parsimony. This highlights the challenges of combining transdisciplinary methods and calls for a consistent method of measuring social 
networks and investigating social network processes with regard to health behaviors. This might also facilitate more formal assessments of publication bias in future research.

It is important to consider that only one study was set in a low-income country ${ }^{68}$, therefore the findings may be generalizable only to adolescents in high-income countries, and there is a need for health behavior and social network studies to be conducted in low-middle income countries. The studies included in the review included a combination of longitudinal and cross-sectional studies, however many used a cross-sectional measure of the network or of the health behavior. The NOS adapted for cross-sectional studies ${ }^{41}$ was therefore applicable for a consistent measure of risk of bias across the studies. However, it should be acknowledged that a limitation of this review is that the risk of bias tool was not adapted for different study design. Furthermore, the included studies were limited to English language only. It is important to consider context when interpreting the findings of this review. Whilst we have highlighted the importance of social network processes and their association with health behaviors in adolescents, it should be acknowledged that these processes do not operate in isolation, but are acting within a broader range of socio-environmental influences $^{31}$. Previous research has shown that social networks have an important role within the broader social environment context ${ }^{32}$. However, there is a need to consider other mechanisms by which social networks interact within the social environment to impact health behaviors.

\section{Conclusion}

This systematic review has identified two network-behavior patterns and four main underlying mechanisms as important network processes contributing to all included health behaviors. Health behavior similarity could be driven by (a) homophilic social selection; and/or (b) social influence. Associations between network popularity and health behaviors could be driven by (a) increases in social status as a result of (dis)engaging in the behavior(s), or (b) changes in the behavior as a result of social status. A substantial body of evidence investigating smoking, drinking and substance use behaviors was identified, with limited evidence to support PA, dietary or weight-management related behaviors. Overall, the review supports evidence for homophilic social selection, individuals selected friends on the basis of similar health behaviors; social influence, individuals were influenced by their friends to adopt or adapt a behavior; and associations between network popularity and health behaviors. 
This review also identified a lack of research surrounding 'other' social network processes, however there was some indication that density potentially played an important role. It also identified the focus on school-based friendship networks, with a lack of research about other types of relationships. This systematic review highlights the importance of peer social networks for establishing and determining an array of individual health behavior choices, and further longitudinal research into these processes is required to better understand how these processes operate over time and across collective behaviors, with the potential to be incorporated within health behavior change interventions.

Word count: 4,893 


\section{Table 1: Eligibility criteria}

1. The study investigated the association between peer social networks and health behavior(s) in adolescents. Peer social networks were defined as relationships (i.e. friendships, acquaintances, classmates, romantic partners) between adolescents. Social networks that included familial or parental relationships were outside the scope of this study and studies which only included these or primarily focused on networks other than peer networks were excluded. Studies were included if the social network data was collected using specific network questions in questionnaires or surveys, through the use of name or position generators (i.e. name up to five of your best male and best female friends in your class) ${ }^{43}$.

2. The primary population were adolescents (mean age within 13-18 years old).

3. The study targeted specific health behavior(s) including alcohol, smoking, substance use, PA and weight-related behaviors (including diet). Adolescence is a critical lifephase for physical and cognitive development, and establishing lifelong habits ${ }^{126-128}$. The World Health Organization (WHO) identified smoking, drinking and substance abuse amongst major risks and solutions in the prevention of adult health problems ${ }^{129}$. Furthermore, from global PA trends it is estimated that less than $20 \%$ of 13-15 year olds are meeting the daily guidelines of 60 minutes of moderate to vigorous PA (MVPA) $)^{130}$. Similarly concerning trends suggest an increase in global consumption of energy dense foods which contribute to increased risk of obesity ${ }^{131}$. Adolescence is a crucial time to address obesity, as research has shown obesity in adolescence tracks in to adulthood ${ }^{132}$ which contribute to a range of social, health and economic issues ${ }^{133}$. Adolescence is an important time to intervene to prevent the development of health-harming behaviors and encourage healthy habits in an effort to reduce the risk of chronic disease later in life ${ }^{134}$. Other health behaviors were beyond the scope of this systematic review.

4. The study measured homophilic social selection, social influence, popularity or a network structural parameter (i.e. density; a measure of how connected individuals in the network are to each other $\left.{ }^{135}\right)$. Homophilic social selection in the peer network context was defined as the tendency for adolescents to purposefully select friends on the basis of similarities in socio-demographic factors, health behaviors or interests ${ }^{13-}$ 15. 'The process of social influence in the peer network context was defined as one or more person(s) or friend(s) in the network influencing another ${ }^{13}$ and resulting in 
peers becoming more similar over time in terms of their health behavior due to spending time together, shared activities, peer norms and modelling of habits ${ }^{16}$. Network popularity was defined as the presence of a high in-degree within a friendship network, measured by receiving a high number of friendship nominations ${ }^{17,18}$.

5. The study statistically tested the association(s) between the specified heath behavior and social network parameter(s)/process(es). The statistical methods employed by the studies were not restricted, due to the heterogeneity of the studies' analysis techniques (including standard statistical techniques for independent data such as regression, or analytical techniques accounting for the dependent relational nature of the data, such as ERGM and SAOM).

6. The full text was available in English.

7. There was no restriction on the year of publication.

8. Study design included longitudinal, cross-sectional, observational and interventional peer-reviewed publications. 


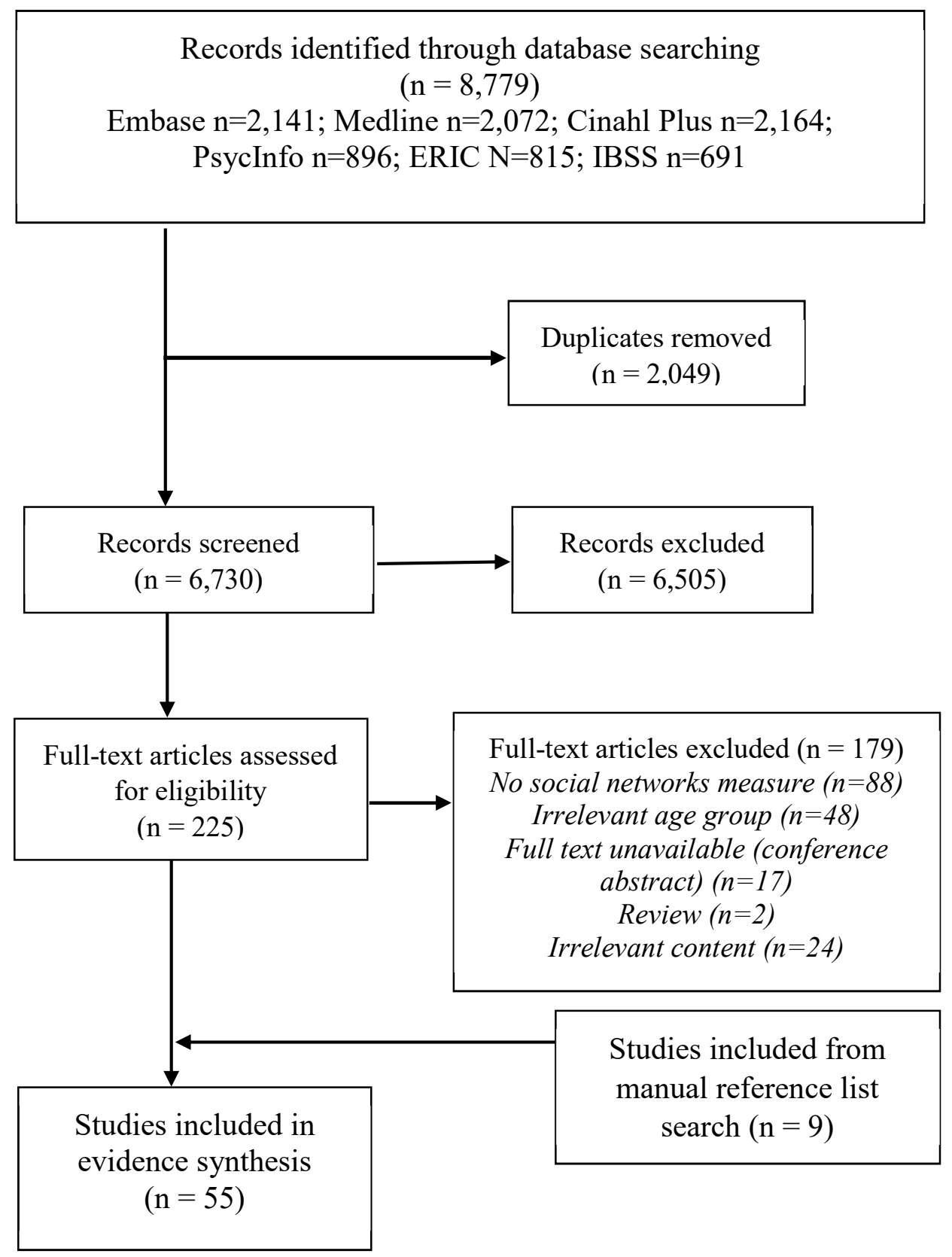

Figure 1: Study Flow Diagram 
Table 2: Studies investigating homophilic social selection (but not social influence)

\begin{tabular}{|c|c|c|c|}
\hline Reference & Study details & Outcome & Study quality \\
\hline \multicolumn{4}{|l|}{ Alcohol drinking } \\
\hline $\begin{array}{l}\text { Crosnoe, Muller and Frank, } 2004^{53} \\
\text { Setting: Home and school } \\
\text { Longitudinal }\end{array}$ & $\begin{array}{l}\mathrm{N}=7,758 ; 53 \% \text { female; mean age } \\
\left.15.72 \text { years (SD not reported }{ }^{\wedge}\right) \\
\text { Country: USA (using Add Health } \\
\text { data) }\end{array}$ & $\begin{array}{l}\text { +ve: Non-drinkers had friends who drank the least: } \\
\text { mean } 0.80 \text {, SD } 1.00 \text {; frequent drinkers }(1) \text { had } \\
\text { friends who drank the most: mean } 1.81 \text {, SD } 1.26\end{array}$ & Good \\
\hline $\begin{array}{l}\text { Cheadle et al., } 2013^{54} \\
\text { Setting: Home and school } \\
\text { Longitudinal }\end{array}$ & $\begin{array}{l}\mathrm{N}=3,561 ; 49 \% \text { female; mean grade } \\
10.27 \text { (age not specified) } \\
\text { Country: USA (using Add Health } \\
\text { data) }\end{array}$ & $\begin{array}{l}\text { Small, positive but NS association for selection } \\
\text { friends with similar drinking habits }\end{array}$ & Good \\
\hline $\begin{array}{l}\text { Fujimoto and Valente, } 2015^{52} \\
\text { Setting: School } \\
\text { Cross-sectional }\end{array}$ & $\begin{array}{l}\mathrm{N}=1,707 ; 52 \% \text { female; mean age } \\
15.07 \text { years (SD 0.43) } \\
\text { Country: USA }\end{array}$ & $\begin{array}{l}\text { +ve: Friends' drinking was significantly associated } \\
\text { with individual's drinking: AOR } 1.88^{* *} \text {, SE } 0.36\end{array}$ & Fair \\
\hline \multicolumn{4}{|l|}{ Cigarette smoking } \\
\hline $\begin{array}{l}\text { Alexander et al., } 2001^{55} \\
\text { Setting: Home and school } \\
\text { Cross-sectional }\end{array}$ & $\begin{array}{l}\mathrm{N}=2525,50 \% \text { female; mean age } \\
15.5 \text { years (SD 1.50) } \\
\text { Country: USA (using Add Health } \\
\text { data) }\end{array}$ & $\begin{array}{l}\text { +ve: Adolescents were more than twice as likely to } \\
\text { smoke: OR } 1.91^{* * *} \text {, SE } 0.11 \text { if they had smoking } \\
\text { friends, compared to adolescents who had no } \\
\text { smoking friends } \\
\text { +ve: Adolescents were twice as likely to smoke if } \\
\text { their best friend smoked: OR } 2.00^{* * *} \text {, SE } 0.36\end{array}$ & Good \\
\hline $\begin{array}{l}\text { Schaefer, Adams and Haas, } 2013^{56} \\
\text { Setting: Home and school } \\
\text { Longitudinal }\end{array}$ & $\begin{array}{l}\mathrm{N}=509 ; 46.6 \% \text { female; mean age } \\
\text { not reported } \\
\text { Country: USA (using Add Health } \\
\text { data) }\end{array}$ & $\begin{array}{l}\text { +ve: Adolescents with similar levels of smoking } \\
\text { were more likely to be friends: coef } 0.68^{* * *}, \mathrm{SE} \\
0.12\end{array}$ & Poor \\
\hline \multicolumn{4}{|l|}{ Drinking and smoking combined } \\
\hline Kreager, Haynie and Hopfer, $2013^{47}$ & $\begin{array}{l}\mathrm{N}=1,488,50 \% \text { female; mean age } \\
13-15 \text { (SD not reported) }\end{array}$ & $\begin{array}{l}\text { +ve: Romantic partner's behavior was associated } \\
\text { with individual smoking: coef } 0.77^{* *} \text {. Individual }\end{array}$ & Poor \\
\hline
\end{tabular}




\begin{tabular}{|c|c|c|c|}
\hline $\begin{array}{l}\text { Setting: School } \\
\text { Longitudinal }\end{array}$ & $\begin{array}{l}\text { Country: USA (using Add Health } \\
\text { data) }\end{array}$ & $\begin{array}{l}\text { smoking was associated with having smoking } \\
\text { friends: coef } 1.19^{*} \\
\text { +ve: Individual drinking was associated with } \\
\text { having drinking friends: coef } 0.64^{* *}-1.34^{* *} \\
\text { NS association between individual and partner's } \\
\text { drinking }\end{array}$ & \\
\hline \multicolumn{4}{|l|}{ Physical Activity } \\
\hline $\begin{array}{l}\text { De la Haye et al., } 2010^{57} \\
\text { Setting: School } \\
\text { Cross-sectional }\end{array}$ & $\begin{array}{l}\mathrm{N}=385 ; 64 \% \text { female; mean age } 13- \\
14 \text { years }(S D \text { not reported) } \\
\text { Country: Australia }\end{array}$ & $\begin{array}{l}\text { +ve: Positive and significant effects(2) of engaging } \\
\text { in similar amounts of organized PA was found for } \\
\text { both male and female friends in } 2 \text { out of } 3 \text { networks } \\
\text { in the final model: male PE }-0.10--0.08 \text {; SE } 0.03 \text { - } \\
0.03(1) \text {; female PE }-0.06-0.07 \text {; SE } 0.03-0.04\end{array}$ & Fair \\
\hline $\begin{array}{l}\text { Schofield et al., } 2007^{58} \\
\text { Setting: School } \\
\text { Cross-sectional (Four-day observational } \\
\text { study) }\end{array}$ & $\begin{array}{l}\mathrm{N}=318 ; 100 \% \text { female; mean age } 16 \\
\text { years (SD 0.80) } \\
\text { Country: Australia }\end{array}$ & $\begin{array}{l}+ \text { ve: Correlation between individual and friend }\left(1^{\text {st }}\right. \\
-3^{\text {rd }} \text { nominated friends) was stronger for } \\
\text { reciprocated friends: coef } 0.45-0.16 \text { than non- } \\
\text { reciprocated friends: coef }-0.06-0.16 \\
+ \text { ve: Individual PA was associated with PA of } 1^{\text {st }} \\
\text { nominated friend only: coef } 0.41^{* * * *}\left(2^{\text {nd }} \text { and } 3^{\text {rd }}\right. \\
N S)\end{array}$ & Poor \\
\hline \multicolumn{4}{|l|}{ Dietary-related behaviors } \\
\hline $\begin{array}{l}\text { Bruening et al., } 2012^{59} \\
\text { Setting: School } \\
\text { Cross-sectional }\end{array}$ & $\begin{array}{l}\mathrm{N}=2,043 \text {; female } 46.2 \% \text {; mean age } \\
14.2 \text { years (SD } 1.9 \text { ) } \\
\text { Country: USA }\end{array}$ & $\begin{array}{l}\text { +ve: Individual breakfast intake was associated } \\
\text { with friend group: coef } 0.26^{* * *}, 95 \% \text { CI } 0.14 \text { - } \\
0.38 \text { and best friends' intake: coef } 0.19 *, 95 \% \text { CI } \\
0.06-0.32 \\
\text { NS association for friend group/best friends and } \\
\text { individual fruit intake or friend group and } \\
\text { vegetable intake } \\
\text { +ve: Vegetable intake was associated with the best } \\
\text { friends' intake: coef } 0.09^{*}, 95 \% \text { CI } 0.01-0.18\end{array}$ & Good \\
\hline
\end{tabular}




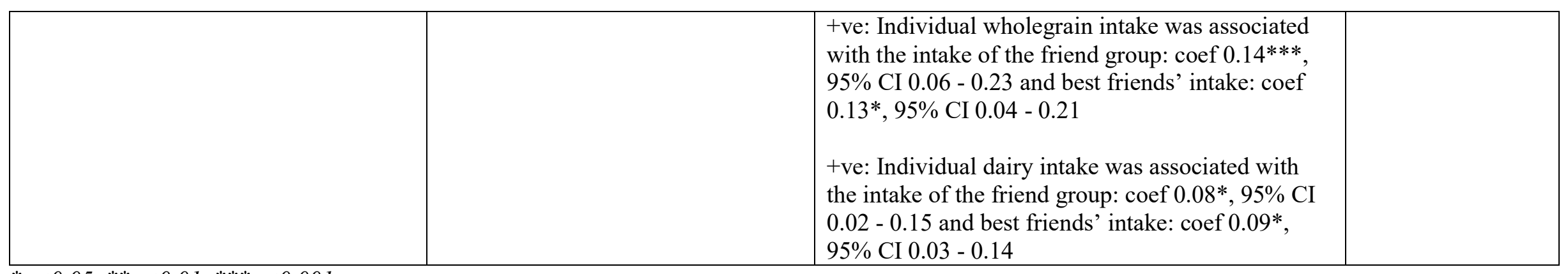

${ }^{*} p<0.05, * * p<0.01,{ }^{* * *} p<0.001$

Italic script indicates missing information or non-significant findings

$+v e$ : Study showed positive and statistically significant association

AOR: Adjusted Odds Ratio; CI: Confidence Intervals; coef: coefficient; NS: Non-Significant at 5\% significance level; OR: Odds Ratio; PA: Physical Activity; PE: Parameter Estimate; SD: Standard Deviation; SE: Standard Error

(1) Frequent drinkers drank alcohol more than once a month ${ }^{53}$

(2) ERGM practice assumes significance if the PE is more than twice it's $S E^{57}$ 
Table 3: Studies investigating social influence (but not homophilic social selection)

\begin{tabular}{|c|c|c|c|}
\hline Reference & Study details & Outcome & Study quality \\
\hline \multicolumn{4}{|l|}{ Alcohol drinking } \\
\hline $\begin{array}{l}\text { Ali and Dwyer, } 2010^{69} \\
\text { Setting: Home and school } \\
\text { Cross-sectional }\end{array}$ & $\begin{array}{l}\mathrm{N}=20,097,51 \% \text { female; mean age } \\
15 \text { years (SD not reported }{ }^{\wedge} \text { ) } \\
\text { Country: USA (using Add Health } \\
\text { data) }\end{array}$ & $\begin{array}{l}\text { +ve: Only same-grade peers' drinking was } \\
\text { significantly associated with increased individual } \\
\text { drinking: coef } 0.41 * \text {, SE } 0.15 \text { (10\% increase in } \\
\text { classmates' drinking resulted in an increase in } \\
\text { individual's drinking and frequency of alcohol } \\
\text { consumption by approximately } 4 \%) \\
\text { NS association between friend and individual drinking }\end{array}$ & Good \\
\hline $\begin{array}{l}\text { Giletta et al., } 2012^{66} \\
\text { Setting: School } \\
\text { Longitudinal }\end{array}$ & $\begin{array}{l}\mathrm{N}=704 ; 47 \% \text { female; mean age } \\
15.53 \text { years (SD not reported) } \\
\text { Country: Italy }\end{array}$ & $\begin{array}{l}\text { +ve: Individual alcohol use became more similar to } \\
\text { their peers' use over time: PE } 0.48, \text { SE } 0.15^{* * *} \\
\text { +ve: Same sex dyadic friendships became more } \\
\text { similar over time in their alcohol misuse for both male } \\
\text { and female same-sex dyads but not for mixed sex } \\
\text { dyads: coef } 0.22^{* * *}-0.47^{*}\end{array}$ & Good \\
\hline $\begin{array}{l}\text { Gallupe and Bouchard, } 2015^{67} \\
\text { Setting: Home and school } \\
\text { Longitudinal }\end{array}$ & $\begin{array}{l}\mathrm{N}=13,351 ; 50 \% \text { female; mean age } \\
14.75 \text { years (SE } 0.01 \text { ) } \\
\begin{array}{l}\text { Country: USA (using Add Health } \\
\text { data) }\end{array}\end{array}$ & $\begin{array}{l}\text { +ve: Associating with alcohol using friends at TP } 1 \\
\text { predicted individual alcohol use at TP } 2 \text { : coef } 0.35^{* *} \text {, } \\
\text { SE } 0.01\end{array}$ & Good \\
\hline $\begin{array}{l}\text { Lee et al., } 2015^{68} \\
\text { Setting: School } \\
\text { Longitudinal }\end{array}$ & $\begin{array}{l}\mathrm{N}=1,808 ; 53 \% \text { female, (age not } \\
\text { reported) } \\
\text { Country: Northern Taiwan }\end{array}$ & $\begin{array}{l}\text { +ve: Adolescents who had drinking peers tended to } \\
\text { drink more often during the past year: aPRR } 3.02 \text {, } \\
95 \% \text { CI } 1.92-4.75^{* * *} \text {, whereas those who had peers } \\
\text { against drinking tended to drink less: aPRR } 0.21,95 \% \\
\text { CI } 0.16-0.27^{* * *}\end{array}$ & Good \\
\hline $\begin{array}{l}\text { Gaughan, } 2006^{49} \\
\text { Setting: Home and school } \\
\text { Cross-sectional }\end{array}$ & $\begin{array}{l}\mathrm{N}=2,902 ; 52 \% \text { female; mean age } \\
16.55 \text { years (SD 1.46) } \\
\text { Country: USA (using Add Health } \\
\text { data) }\end{array}$ & $\begin{array}{l}\text { +ve: Same-sex dyadic friendships mutually influence } \\
\text { each others' drinking: coef } 0.41^{* * *}-0.77^{* * *} \text {, SE } 0.01 \\
-0.17 \text {; however males in a mixed sex friendship } \\
\text { influence their female friends to drink: coef } 0.35^{*}- \\
0.38^{* *} \text {, SE } 0.12-0.16 \text {, but are not influenced by them }\end{array}$ & Fair \\
\hline
\end{tabular}




\begin{tabular}{|c|c|c|c|}
\hline \multicolumn{4}{|l|}{ Cigarette smoking } \\
\hline $\begin{array}{l}\text { Ali and Dwyer, } 2009^{65} \\
\text { Setting: Home and school } \\
\text { Longitudinal }\end{array}$ & $\begin{array}{l}\mathrm{N}=20,745,51 \% \text { female; mean age } \\
15.2 \text { years (SD 1.74) } \\
\text { Country: USA (using Add Health } \\
\text { data) }\end{array}$ & $\begin{array}{l}\text { +ve: School grade-level peer smoking influenced } \\
\text { adolescent smoking to a greater extent: OLS } 0.40^{* *} \text { - } \\
0.15^{* *} \text {, SE } 0.03-0.02 \text {, compared to influence from } \\
\text { nominated peers: OLS } 0.21^{* *}-0.15^{* *} \text {, SE } 0.01- \\
0.02 \text {, at all } 3 \text { waves }\end{array}$ & Good \\
\hline $\begin{array}{l}\text { Lakon, Hipp and Timberlake, } 2010^{70} \\
\text { Setting: Home and school } \\
\text { Longitudinal }\end{array}$ & $\begin{array}{l}\mathrm{N}=6,504 ; 38.2 \% \text { female; mean age } \\
14.87 \text { years (SD 1.73) } \\
\text { Country: USA (using Add Health } \\
\text { data) }\end{array}$ & $\begin{array}{l}\text { +ve: Friends' smoking behavior was associated with } \\
\text { increasing individual smoking at both TPs: coef } \\
0.77^{* *}, \text { SE } 0.05 \text { and coef } 0.32^{* *}, \text { SE } 0.05\end{array}$ & Good \\
\hline \multicolumn{4}{|l|}{ Drinking and smoking combined } \\
\hline $\begin{array}{l}\text { Fujimoto and Valente, } 2012 \mathrm{~b}^{60} \\
\text { Setting: Home and school } \\
\text { Cross-sectional }\end{array}$ & $\begin{array}{l}\mathrm{N}=13,187 ; 52 \% \text { female; mean age } \\
15.04 \text { years (SD 1.70) } \\
\begin{array}{l}\text { Country: USA (using Add Health } \\
\text { data) }\end{array}\end{array}$ & $\begin{array}{l}\text { +ve: Adolescents were most influenced to drink by } \\
\text { direct friends: OR } 1.57^{* * *} \text { over indirect(3) friends (2- } \\
4 \text { distances out): OR } 1.44^{* *}-1.16^{* *} \\
\text { Adolescents were most influenced to smoke by their } \\
\text { direct friends: OR } 2.36^{* * *} \text {, over indirect(3) friends at } \\
\text { distance } 2 \text { : OR } 2.30^{* * *} \text {. NS influence effect from } \\
\text { friends at distances } 3-4\end{array}$ & Good \\
\hline $\begin{array}{l}\text { Fujimoto and Valente, } 2012 \mathrm{a}^{71} \\
\text { Setting: Home and school } \\
\text { Cross-sectional }\end{array}$ & $\begin{array}{l}\mathrm{N}=2,533 ; 50 \% \text { female; mean age } \\
15.49 \text { years (SD 1.49) } \\
\text { Country: USA (using Add Health } \\
\text { data) }\end{array}$ & $\begin{array}{l}\text { +ve: Adolescents were influenced more by their friend } \\
\text { group than their best friends for drinking: AOR } \\
2.62 * * * \mathrm{v} 1.55^{* * *} \text {, and smoking: AOR } 3.32 * * * \mathrm{v} \\
2.39 * * *\end{array}$ & Good \\
\hline $\begin{array}{l}\text { Urberg, Degirmencioglu and } \\
\text { Pilgrim, } 1997^{61} \\
\text { Setting: School } \\
\text { Longitudinal }\end{array}$ & $\begin{array}{l}\mathrm{N}=1,028 ; 50.6 \% \text { female; mean age } \\
\text { not reported }\left(6^{\text {th }}-10^{\text {th }} \text { grade }\right) \\
\text { Country: USA }\end{array}$ & $\begin{array}{l}+ \text { ve: Initiation of individual smoking was predicted by } \\
\text { close friend smoking: coef } 0.73 * * * \text { and drinking coef } \\
0.37 * * \\
+ \text { ve: Friend group predicted current smoking: coef } \\
2.20^{* * *} \text { and close friend predicted current drinking: } \\
\text { coef } 0.32^{*}\end{array}$ & Poor \\
\hline
\end{tabular}




\begin{tabular}{|c|c|c|c|}
\hline $\begin{array}{l}\text { French, Purwono and Rodkin, } \\
2014^{62} \\
\text { Setting: School } \\
\text { Longitudinal }\end{array}$ & $\begin{array}{l}\mathrm{N}=992,52.8 \% \text { female; mean age } \\
\text { 8th grade } 13.37(\mathrm{SD} 0.45) ; 10 \text { th } \\
\text { grade } 15.36(\mathrm{SD} 0.52) \\
\text { Country: Bandung, West Java }\end{array}$ & $\begin{array}{l}\text { +ve: Controlling for use at TP } 1 \text {, friends' and } \\
\text { classmates alcohol use predicted boys' alcohol use at } \\
\text { TP } 2 \text { : (no label) } 1.01^{*} \text { and } 3.26^{* * *} \text { respectively (NS } \\
\text { effect for girls) } \\
\text { Friends' and classmates' smoking predicted use for } \\
\text { both boys: } 1.45^{* *} \text { and } 1.49^{* *} \text {; and girls: } 1.52 * * * \text { and } \\
2.43^{* * *}\end{array}$ & Poor \\
\hline \multicolumn{4}{|l|}{ Substance use } \\
\hline $\begin{array}{l}\text { Valente et al., } 2007^{48} \\
\text { Setting: School } \\
\text { Longitudinal (intervention) }\end{array}$ & $\begin{array}{l}\mathrm{N}=541 ; 38 \% \text { female; mean age } \\
16.3 \text { years }(\mathrm{SD} 1.36) \\
\text { Country: USA }\end{array}$ & $\begin{array}{l}\text { +ve: Relative to control, TND intervention }(4) \text { was not } \\
\text { associated with changes in substance use, but } \\
\text { receiving TND-network intervention was associated } \\
\text { with decreased marijuana use: coef }-0.64,95 \% \mathrm{CI} \text { - } \\
1.09--0.19 * \text { and cocaine use: coef }-0.37,95 \% \mathrm{CI} \text { - } \\
0.63--0.10^{*} \\
\text {-ve: The interaction of peer use and TND-network was } \\
\text { associated with increases in substance use: coef } \\
0.17 * *, 95 \% \text { CI } 0.08-0.26 \text { (it could accelerate } \\
\text { negative peer influence) }\end{array}$ & Good \\
\hline $\begin{array}{l}\text { Coronges, Stacy and Valente, } 2011^{63} \\
\text { Setting: School } \\
\text { Longitudinal }\end{array}$ & $\begin{array}{l}\mathrm{N}=567,43 \% \text { female; age not } \\
\text { reported } \\
\text { Country: USA }\end{array}$ & $\begin{array}{l}\text { +ve: Friends' drug use increased individual use for } \\
\text { marijuana: OR 1.95, SE } 0.73 * \\
\text { NS effect for friends' drug use increasing individual } \\
\text { use for alcohol }\end{array}$ & Fair \\
\hline \multicolumn{4}{|l|}{ Physical Activity } \\
\hline $\begin{array}{l}\text { Lopes, Gabbard and Rodrigues, } \\
2013^{39} \\
\text { Setting: School } \\
\text { Cross-sectional }\end{array}$ & $\begin{array}{l}\mathrm{N}=268 ; 47.8 \% \text { female, aged } \\
\text { between } 13-18 \text { years (SD not } \\
\text { reported) } \\
\text { Country: Portugal }\end{array}$ & $\begin{array}{l}\text { +ve: Best friend dyads show a moderate and } \\
\text { significant degree of association with VPA, MPA and } \\
\text { sitting time behavior: VPA coef } 0.32 * * * ; \text { MPA coef } \\
0.31 * * * \text { and sitting coef } 0.21 * \\
\text { NS effect for walking }\end{array}$ & Poor \\
\hline \multicolumn{4}{|l|}{ Dietary-related behaviors } \\
\hline Ali et al., $2012^{64}$ & $\begin{array}{l}\mathrm{N}=20,745 ; 50 \% \text { female; mean age } \\
15.18 \text { years (SD } 1.16)\end{array}$ & & Good \\
\hline
\end{tabular}




\begin{tabular}{|l|l|l|l|}
\hline Setting: Home and school & $\begin{array}{l}\text { Country: USA (using Add Health } \\
\text { data) }\end{array}$ & $\begin{array}{l}\text { NS effects for close friends' BMI or same-school } \\
\text { peers' BMI on adolescents' BMI }\end{array}$ & \\
\hline
\end{tabular}

${ }^{*} p<0.05, * * p<0.01, * * * p<0.001$

Italic script indicates missing information or non-significant findings

+ve: Study showed positive and statistically significant association; -ve: study showed negative and statistically significant association

aPRR: adjusted prevalence rate ratio; BMI: Body Mass Index; CI: Confidence Interval; coef: coefficient; MPA: Moderate Physical Activity; NS: Non-

Significant at 5\% significance level; OLS: Odd Least Squares; OR: Odds Ratio; PA: Physical Activity; PE: Parameter Estimate; SD: Standard Deviation;

SE: Standard Error; TP: Time-point

(3) Indirect friends are friends of a friend; or friends of a friend of a friend; i.e. indirectly tied to the adolescent through another tie ${ }^{60}$

(4) Post intervention results of receiving the TND (Towards No Drug abuse) intervention, or TND-network (nominated peer leaders delivered discussions and teams identified through group project nominations) $)^{48}$ 
Table 4: Studies investigating both homophilic social selection and social influence

\begin{tabular}{|c|c|c|c|c|}
\hline Reference & Study details & Selection & Influence & Study quality \\
\hline \multicolumn{5}{|l|}{ Alcohol drinking } \\
\hline $\begin{array}{l}\text { Mundt, Mercken and } \\
\text { Zakletskaia, 2012 } \\
\text { Setting: Home and school } \\
\text { Longitudinal }\end{array}$ & $\begin{array}{l}\mathrm{N}=2,563 ; 49 \% \text { female; mean } \\
\text { age } 15.80 \text { years (SD 1.3) } \\
\text { Country: USA (using Add } \\
\text { Health data) }\end{array}$ & $\begin{array}{l}+ \text { ve: Friend selection was } \\
\text { associated with similar alcohol } \\
\text { use: coef } 1.28, \text { SE } 0.21^{* * *}\end{array}$ & $\begin{array}{l}\text { NS influence effect based on } \\
\text { alcohol consumption. NS } \\
\text { association for more frequent } \\
\text { drinking by immediate friends } \\
\text { leading to increased frequency } \\
\text { of individual alcohol } \\
\text { consumption }\end{array}$ & Good \\
\hline $\begin{array}{l}\text { Mercken et al., } 2012^{80} \\
\text { Setting: School } \\
\text { Longitudinal }\end{array}$ & $\begin{array}{l}\mathrm{N}=1,204 ; 48.8 \% \text { female, } \\
\text { mean age at baseline } 13.60 \\
\text { years (SD not reported) } \\
\text { Country: Finland }\end{array}$ & $\begin{array}{l}\text { NS association for alcohol } \\
\text { consumption-based selection } \\
\text { effects in period } 1 \text { (TP } 1-T P \\
\text { 2) } \\
\text { Adolescents who had high } \\
\text { alcohol consumption tended to } \\
\text { select friends who likewise had } \\
\text { high alcohol consumption at } \\
\text { periods } 2 \text { (TP } 2-\mathrm{TP} 3): \mathrm{x}^{2} \\
40.07^{*} \text { and } 3 \text { (TP 3 - TP 4): } \mathrm{x}^{2} \\
34.29^{*}\end{array}$ & $\begin{array}{l}\text { +ve: During TP } 1-\text { TP } 2 \text {, } \\
\text { adolescents alcohol } \\
\text { consumption was influenced by } \\
\text { their friends' alcohol } \\
\text { consumption: } \mathrm{x}^{2} 38.25^{*} \\
\text { NS effect from TP } 2-T P 3 \text {, and } \\
\text { TP } 3-T P 4\end{array}$ & Good \\
\hline $\begin{array}{l}\text { Kreager and Haynie, } 2011^{46} \\
\text { Setting: Home and school } \\
\text { Longitudinal }\end{array}$ & $\begin{array}{l}\mathrm{N}=14,738,50 \% \text { female; } \\
\text { mean age } 14.18 \text { years } \\
\text { (females, SD } 1.51) ; 14.78 \\
\text { years (male, SD } 1.65 \text { ) } \\
\text { Country: USA (using Add } \\
\text { Health data) }\end{array}$ & $\begin{array}{l}\text { +ve: } 1 \text { SD increase in (a) } \\
\text { partner's prior drinking } \\
\text { increases respondents' odds of } \\
\text { binge drinking by } 32 \% \text {, (b) } \\
\text { friends' prior drinking increases } \\
\text { the odds of binge drinking by } \\
30 \% \text {, and (c) friends-of-partner } \\
\text { prior drinking increases the } \\
\text { odds of binge drinking by } 81 \%\end{array}$ & $\begin{array}{l}\text { +ve: After controlling for prior } \\
\text { individual drinking, 1 SD } \\
\text { increase in romantic partner's } \\
\text { prior drinking increased } \\
\text { individual's odds of binge } \\
\text { drinking by } 43 \% \text { (OR } 1.43^{* *} \text { ) } \\
\text { Friends' prior drinking was no } \\
\text { longer associated with } \\
\text { increased individual drinking } \\
\text { after controlling for own prior } \\
\text { drinking }\end{array}$ & Good \\
\hline
\end{tabular}




\begin{tabular}{|c|c|c|c|c|}
\hline $\begin{array}{l}\text { Long, Barrett and Lockhart, } \\
2017^{85} \\
\text { Setting: Home and School } \\
\text { Longitudinal }\end{array}$ & $\begin{array}{l}\mathrm{N}=1,796 ; 47.8 \% \text { female; } \\
\text { mean age } 16.40 \text { years (SD not } \\
\text { reported) } \\
\text { Country: USA (using Add } \\
\text { Health data) }\end{array}$ & $\begin{array}{l}+ \text { ve: Friend selection was } \\
\text { associated with similar alcohol } \\
\text { use in both schools: coef } 0.93- \\
1.46 \text {, SE } 0.23-0.34^{* * *}\end{array}$ & $\begin{array}{l}\text { +ve: Adolescents changed their } \\
\text { alcohol use behavior to become } \\
\text { more similar to their friends in } \\
\text { one of two schools: coef } 0.62 \text {, } \\
\text { SE } 0.30^{*}\end{array}$ & Poor \\
\hline $\begin{array}{l}\text { Wang et al., } 2017^{86} \\
\text { Setting: Home and School } \\
\text { Longitudinal }\end{array}$ & $\begin{array}{l}\mathrm{N}=3,154 ;(\% \text { female } n o t \\
\text { reported); } 7^{\text {th }}-12^{\text {th }} \text { grades } \\
\text { Country: USA (using Add } \\
\text { Health data) }\end{array}$ & $\begin{array}{l}+ \text { ve: Friend selection was } \\
\text { associated with similar alcohol } \\
\text { use (in one of two schools): } \\
\text { coef } 0.18 \text {, SE } 0.03^{*}\end{array}$ & $\begin{array}{l}\text { +ve: Adolescents were } \\
\text { influenced to drink by their } \\
\text { friends (in both schools): coef } \\
0.38-0.48^{*} \text {, SE } 0.07-0.16\end{array}$ & Poor \\
\hline \multicolumn{5}{|l|}{ Cigarette smoking } \\
\hline $\begin{array}{l}\text { Mercken et al., } 2010^{89} \\
\text { Setting: School } \\
\text { Longitudinal }\end{array}$ & $\begin{array}{l}\mathrm{N}=1,326 ; 47 \% \text { female; mean } \\
\text { age } 13.4 \text { years (SD not } \\
\text { reported) } \\
\text { Country: Finland }\end{array}$ & $\begin{array}{l}\text { +ve: Adolescents who were } \\
\text { smokers, selected smoking } \\
\text { friends: coef } 0.09^{* * *} \text {, SE } 0.02 \\
\text { (significant only for a) } \\
\text { unilateral(5) friendships - the } \\
\text { interaction decreased for } \\
\text { reciprocated friends) } \\
\text { Network autocorrelation } \\
\text { attributed to smoking-based } \\
\text { selection was higher than the } \\
\text { proportion allocated to } \\
\text { influence for all } 3 \text { waves ( } 31 \text { - } \\
46 \% \mathrm{v} 15-22 \% \text { ) }\end{array}$ & $\begin{array}{l}\text { +ve: Adolescents adjusted their } \\
\text { smoking status to become more } \\
\text { similar to their friends' } \\
\text { smoking status: coef } 0.21^{* *} \text {, } \\
\text { SE } 0.07\end{array}$ & Good \\
\hline $\begin{array}{l}\text { Go et al., } 2012^{88} \\
\text { Setting: Home and School } \\
\text { Longitudinal }\end{array}$ & $\begin{array}{l}\mathrm{N}=2,065 ; 50.5 \% \text { female; } \\
\text { mean age not reported }(11 \% \\
7 \text { th grade, } 11.3 \% 8^{\text {th }}, 10.9 \% \\
9^{\text {th }}, 31.5 \% 10^{\text {th }}, 28.7 \% 11^{\text {th }}, \\
\left.6.6 \% 12^{\text {th }}\right) \\
\text { Country: USA (using Add } \\
\text { Health data) }\end{array}$ & $\begin{array}{l}\text { +ve: Smoking initiation was } \\
\text { associated with selecting a new } \\
\text { smoking friend: OR } 2.18^{* * *} \text {, } \\
95 \% \text { CI } 1.27-3.76\end{array}$ & $\begin{array}{l}\text { +ve: Each consistent smoking } \\
\text { friend ( } 1 \text { degree away) } \\
\text { increases the likelihood of an } \\
\text { adolescent initiating smoking } \\
\text { by } 80 \% \text { (OR } 1.79^{* * *}, 95 \% \text { CI } \\
1.38-2.34)\end{array}$ & Good \\
\hline
\end{tabular}




\begin{tabular}{|c|c|c|c|c|}
\hline $\begin{array}{l}\text { Valente, Fujimoto, Soto et al., } \\
2013^{81} \\
\text { Setting: School } \\
\text { Longitudinal }\end{array}$ & $\begin{array}{l}\mathrm{N}=1,950 ; 58.6 \% \text { female; } \\
\text { mean age } 14 \text { years (SD not } \\
\text { reported) } \\
\text { Country: USA }\end{array}$ & $\begin{array}{l}\text { +ve: Respondents who changed } \\
\text { smoking status and made new } \\
\text { friends with others of the same } \\
\text { smoking status were more } \\
\text { likely to become a smoker at } \\
\text { TP 2: AOR } 1.32(\mathrm{p}=0.05)\end{array}$ & $\begin{array}{l}\text { +ve: Friend's smoking (at } \\
\text { baseline) was associated with } \\
\text { initiation of individual smoking } \\
\text { at TP } 2 \text { : AOR } 1.72 * \text {, SE } 0.43 \\
\text { (sociocentric measure) } \\
\text { Increase in perceived friends' } \\
\text { smoking was associated with } \\
\text { becoming a smoker AOR: } \\
1.84 * * \text {, SE } 0.12 \text {, CI } 1.61- \\
2.09 \text { (egocentric measure) }\end{array}$ & Fair \\
\hline $\begin{array}{l}\text { Go et al., } 2010^{87} \\
\text { Setting: Home and School } \\
\text { Longitudinal }\end{array}$ & $\begin{array}{l}\mathrm{N}=1,223 ; 52 \% \text { female; mean } \\
\text { age } 15.5 \text { years (SD not stated) } \\
\text { Country: USA (using Add } \\
\text { Health data) }\end{array}$ & $\begin{array}{l}\text { +ve: Initial smokers and non- } \\
\text { smokers were more likely to } \\
\text { join a smoking friendship } \\
\text { group and non-smoking } \\
\text { friendship group over time, } \\
\text { respectively: OR } 1.95^{* * *}, 95 \% \\
\text { CI } 1.35-2.83\end{array}$ & $\begin{array}{l}\text { +ve: Initial non-smokers in a } \\
\text { smoking friendship group were } \\
\text { about } 1.5 \text { times more likely } \\
\text { (than those in a non-smoking } \\
\text { group) to start smoking by TP } \\
\text { 2: OR } 1.48,95 \% \text { CI } 1.03-2.15 \\
\text { +ve: Initial smokers in a non- } \\
\text { smoking group were twice as } \\
\text { likely to be non-smokers by TP } \\
2 \text { compared to initial smokers } \\
\text { in a smoking group at TP } 1: \text { OR } \\
2.13,95 \% \text { CI } 1.1-4.06\end{array}$ & Poor \\
\hline $\begin{array}{l}\text { Huisman and Bruggeman, } \\
2012^{79} \\
\text { Setting: School } \\
\text { Longitudinal }\end{array}$ & $\begin{array}{l}\mathrm{N}=961 ; 51.4 \% \text { female; mean } \\
\text { age } 13.47 \text { years (SD 0.6) } \\
\text { Country: The Netherlands }\end{array}$ & $\begin{array}{l}\text { +ve: Adolescents selected } \\
\text { friends with similar smoking } \\
\text { status: coef } 0.07^{* * *}\end{array}$ & $\begin{array}{l}\text { +ve; Adolescents are } \\
\text { influenced by friends to adopt } \\
\text { their smoking behavior: coef } \\
0.21 *\end{array}$ & Poor \\
\hline $\begin{array}{l}\text { Aloise-Young, Graham and } \\
\text { Hansen, } 1994^{82} \\
\text { Setting: School }\end{array}$ & $\begin{array}{l}\mathrm{N}=1,145 ; 59 \% \text { female (part } \\
1) ; 55 \% \text { (part } 2) ;(\text { mean age } \\
\text { not reported }\left(7^{\text {th }} \text { grade)) }\right. \\
\text { Country: USA }\end{array}$ & $\begin{array}{l}\text { +ve: Smoking similarity } \\
\text { increased the chances of a } \\
\text { unilateral(5) friend becoming a } \\
\text { reciprocal friend by } 15.2 \% \text {. } \\
\text { Although reciprocal friends }\end{array}$ & $\begin{array}{l}\text { +ve: In comparison with a } \\
\text { friendship group outsider with a } \\
\text { non-smoking best friend, a } \\
\text { group outsider whose best } \\
\text { friend smokes is twice as likely }\end{array}$ & Poor \\
\hline
\end{tabular}




\begin{tabular}{|c|c|c|c|c|}
\hline Longitudinal & & $\begin{array}{l}\text { started out more similar in their } \\
\text { smoking behavior: } \mathrm{r} 0.23^{* *}, \\
\text { than unilateral friends: } \mathrm{r} 0.09^{*} \text {, } \\
\text { the new reciprocal friends were } \\
\text { as similar: } \mathrm{r} 0.47^{* *} \text { as the } \\
\text { continuing reciprocal friends: } \mathrm{r} \\
0.37^{* *} \text { at TP } 2\end{array}$ & $\begin{array}{l}\text { to begin smoking during the } \\
\text { next year (probability } 22.7 \mathrm{v} \\
11.2)\left(\mathrm{OR} 2.38^{*}\right)\end{array}$ & \\
\hline $\begin{array}{l}\text { Schaefer, Haas and Bishop, } \\
2012^{90} \\
\text { Setting: Home and School } \\
\text { Longitudinal }\end{array}$ & $\begin{array}{l}\mathrm{N}=509 ; 46.6 \% \text { female; mean } \\
\text { age } 15.39 \text { years (SD not } \\
\text { reported) } \\
\text { Country: USA (using Add } \\
\text { Health data) }\end{array}$ & $\begin{array}{l}\text { +ve: Adolescents selected } \\
\text { friends with similar smoking } \\
\text { behavior: coef } 0.68^{* * *}, \mathrm{SE} \\
0.13\end{array}$ & $\begin{array}{l}\text { +ve: Adolescents adopted their } \\
\text { friends' smoking behavior over } \\
\text { time: coef } 2.88^{* * *} \text {, SE } 0.86\end{array}$ & Poor \\
\hline \multicolumn{5}{|c|}{ Drinking and smoking combined } \\
\hline $\begin{array}{l}\text { Wang et al., } 2016^{73} \\
\text { Setting: Home and School } \\
\text { Longitudinal }\end{array}$ & $\begin{array}{l}\mathrm{N}=2,260 ; 49.9 \% \text { female; } \\
\text { mean age not reported }\left(7^{\text {th }}-\right. \\
12^{\text {th }} \text { grades) } \\
\text { Country: USA (using Add } \\
\text { Health data) }\end{array}$ & $\begin{array}{l}\text { +ve: Adolescents selected } \\
\text { friends with similar smoking: } \\
\text { coef } 0.20^{*}-0.24^{*}, \text { SE } 0.03- \\
0.06 \text { and drinking: coef } 0.13^{*} \text { - } \\
0.14^{*} \text {, SE } 0.04-0.07 \text { behaviors }\end{array}$ & $\begin{array}{l}\text { +ve: Adolescents changed their } \\
\text { smoking: coef } 0.48^{*}-0.77^{*}, \\
\text { SE } 0.12-0.14 \text {, and drinking: } \\
\text { coef } 0.32^{*}-0.45^{*}, \text { SE } 0.12- \\
0.15 \text { behavior to become more } \\
\text { similar to their friends over } \\
\text { time }\end{array}$ & Good \\
\hline $\begin{array}{l}\text { Kiuru et al., } 2010^{72} \\
\text { Setting: School } \\
\text { Longitudinal }\end{array}$ & $\begin{array}{l}\mathrm{N}=1,419 ; 48.6 \% \text { female; } \\
\text { mean age } 16.36 \text { years (SD } \\
1.49) \\
\text { Country: Finland }\end{array}$ & $\begin{array}{l}\text { +ve: Adolescents selected } \\
\text { friends with similar levels of } \\
\text { smoking: PE } 0.53^{* * *}, \text { SE } 0.12 \\
\text { and drinking: PE } 0.90^{* *}, \text { SE } \\
0.37\end{array}$ & $\begin{array}{l}\text { +ve: Individual alcohol use } \\
\text { changed to become more } \\
\text { similar to friends' alcohol use: } \\
\text { PE } 0.78^{* *} \text {, SE } 0.28 \\
\text { NS association for adolescents } \\
\text { adopting similar smoking } \\
\text { behavior to their friends }\end{array}$ & Poor \\
\hline \multicolumn{5}{|l|}{ Substance use } \\
\hline $\begin{array}{l}\text { Wang et al., } 2018^{76} \\
\text { Setting: Home and School }\end{array}$ & $\begin{array}{l}\mathrm{N}=3,128 \\
\text { (\% female and age not } \\
\text { reported) }\end{array}$ & $\begin{array}{l}\text { +ve: Smoking similarity } \\
\text { between peers was significant } \\
\text { for smoking in one of two } \\
\text { schools: coef } 0.24^{*} \text {, SE } 0.10 \text {; }\end{array}$ & $\begin{array}{l}\text { +ve: Individuals in both schools } \\
\text { were influenced by their friends } \\
\text { to smoke: coef } 0.54^{* * *} \text { - } \\
0.77^{* * *} \text {, SE } 0.13-0.15 \text {; drink: }\end{array}$ & Good \\
\hline
\end{tabular}




\begin{tabular}{|c|c|c|c|c|}
\hline Longitudinal & $\begin{array}{l}\text { Country: USA (using Add } \\
\text { Health data) }\end{array}$ & $\begin{array}{l}\text { drinking similarity was } \\
\text { significant in both: coef } 0.12 * \text { - } \\
0.13^{* *} \text {, SE } 0.05 \text {; marijuana } \\
\text { similarity was significant in } \\
\text { both: coef } 0.27 * * *-0.22 * \text {, SE } \\
0.07-0.09\end{array}$ & $\begin{array}{l}\text { coef } 0.28 * *-0.38 *, \text { SE } 0.12- \\
0.16 \text { and use marijuana: coef } \\
1.43^{* *}-1.32 * * *, \text { SE } 0.38- \\
0.49\end{array}$ & \\
\hline $\begin{array}{l}\text { Mathys, Burk and Cillessen, } \\
2013^{51} \\
\text { Setting: School } \\
\text { Longitudinal }\end{array}$ & $\begin{array}{l}\mathrm{N}=450 ; 53 \% \text { female; mean } \\
\text { age } 15.5 \text { years (SD not } \\
\text { reported) } \\
\text { Country: USA }\end{array}$ & $\begin{array}{l}\text { +ve: Adolescents selected } \\
\text { friends with similar smoking: } \\
\text { PE } 0.53 \text {, SE } 0.26^{*} \\
\text { NS effects for friend selection } \\
\text { based on similar alcohol or } \\
\text { marijuana }\end{array}$ & $\begin{array}{l}\text { +ve: Adolescent alcohol } \\
\text { behaviors was significantly } \\
\text { predicted by friends alcohol } \\
\text { behavior: PE } 0.62, \text { SE } 0.26^{*} \\
\text { NS effects for influence based } \\
\text { on smoking or marijuana }\end{array}$ & Fair \\
\hline $\begin{array}{l}\text { Pearson, Steglich and Snijders, } \\
2006^{74} \\
\text { Setting: School } \\
\text { Longitudinal }\end{array}$ & $\begin{array}{l}\mathrm{N}=160, \% \text { female not } \\
\text { reported, aged between 13-15 } \\
\text { years (SD not reported) } \\
\text { Country: Scotland }\end{array}$ & $\begin{array}{l}\text { +ve: Alcohol drinkers selected } \\
\text { friends with similar drinking } \\
\text { habits: PE } 0.96 \text {, SE } 0.38^{*} \\
\text { NS effects for smoking and } \\
\text { marijuana. }\end{array}$ & $\begin{array}{l}\text { +ve: Adolescents adapted their } \\
\text { marijuana and alcohol use } \\
\text { behavior to become more } \\
\text { similar to their friends': PE } \\
3.54, \mathrm{SE} 1.43^{*} \text { and } \mathrm{PE} 1.63, \mathrm{SE} \\
0.43^{* * *} \text { respectively } \\
\text { NS effect for smoking }\end{array}$ & Poor \\
\hline $\begin{array}{l}\text { Poulin et al., } 2011^{75} \\
\text { Setting: School } \\
\text { Longitudinal }\end{array}$ & $\begin{array}{l}\mathrm{N}=143 ; 60 \% \text { female; mean } \\
\text { age } 14.55 \text { years (SD not } \\
\text { reported) } \\
\text { Country: Canada (French } \\
\text { Canada) }\end{array}$ & $\begin{array}{l}\text { Adolescents who used } \\
\text { substances were more likely to } \\
\text { select friends who likewise } \\
\text { used substances: smoking PE } \\
0.50^{* * *}-0.33^{* *} \text {; alcohol PE } \\
0.19^{*}-0.37^{* *} \text {; marijuana PE } \\
0.33^{* *}-0.49^{* *}\end{array}$ & $\begin{array}{l}\text { +ve: Number of new substance } \\
\text { using friends predicted } \\
\text { individual use over time: } \\
\text { smoking PE } 0.18^{*} \text {; alcohol PE } \\
0.26^{* *} \text {; marijuana PE } 0.11^{*} \text { - } \\
0.17^{* *}\end{array}$ & Poor \\
\hline \multicolumn{5}{|l|}{ Physical Activity } \\
\hline $\begin{array}{l}\text { Simpkins et al., } 2013^{77} \\
\text { Setting: Home and school } \\
\text { Longitudinal }\end{array}$ & $\begin{array}{l}\mathrm{N}=1,896 ; 46.6 \% \text { female } \\
\text { (school A), } 48.1 \% \text { female } \\
\text { (school B), mean age } 15.97 \\
\text { years (SD not reported) }\end{array}$ & $\begin{array}{l}\text { +ve: Individuals selected } \\
\text { friends on the basis of similar } \\
\text { PA levels: coef. } 1.38-2.94 ; \mathrm{SE} \\
0.67^{*}-1.28^{*}\end{array}$ & $\begin{array}{l}\text { +ve: Adolescents adopted } \\
\text { similar PA levels to their } \\
\text { friends over time: coef } 0.45 ; \mathrm{SE} \\
0.16^{* * *}-0.23 *\end{array}$ & Good \\
\hline
\end{tabular}




\begin{tabular}{|c|c|c|c|c|}
\hline & Country: USA & & & \\
\hline $\begin{array}{l}\text { De la Haye et al., } 2011^{78} \\
\text { Setting: School } \\
\text { Longitudinal }\end{array}$ & $\begin{array}{l}\mathrm{N}=378 ; 46 \% \text { female; mean } \\
\text { age } 13.6 \text { years (SD } 0.4) \text { in } \\
\text { group } 1 ; 13.7 \text { years (SD } 0.04) \\
\text { years in group } 2 \\
\text { Country: Australia }\end{array}$ & $\begin{array}{l}\text { +ve: Friendship selection (best } \\
\text { friend) significantly predicted } \\
\text { by similarities in PA: PE } 0.62 \text {, } \\
\text { SE } 0.25^{*}\end{array}$ & $\begin{array}{l}\text { +ve: Adolescents' PA behavior } \\
\text { changed over time so it became } \\
\text { or remained similar to that of } \\
\text { their best friend's: PE } 2.67, \mathrm{SE} \\
0.89 * * \\
\text { Network autocorrelation } \\
\text { models showed stronger effects } \\
\text { for influence }(29-47 \%) \text { than } \\
\text { selection }(11-23 \%)\end{array}$ & Fair \\
\hline \multicolumn{5}{|c|}{ Dietary/weight-related behaviors } \\
\hline $\begin{array}{l}\text { De la Haye et al., } 2013^{50} \\
\text { Setting: School } \\
\text { Longitudinal }\end{array}$ & $\begin{array}{l}\mathrm{N}=378 ; 46.3 \% \text { female; mean } \\
\text { age } 13.6 \text { years ( } 13.6 \text { years } \\
\text { (SD 0.4) in school } 1 \text { and } 13.7 \\
\text { years (SD 0.4) in school 2) } \\
\text { Country: Australia }\end{array}$ & $\begin{array}{l}\text { NS effect in either school that } \\
\text { adolescents selected friends } \\
\text { whose intake of LNED foods } \\
\text { was similar to themselves }\end{array}$ & $\begin{array}{l}\text { +ve: Over time, adolescents' } \\
\text { intake of LNED foods became } \\
\text { more similar to their friends' } \\
\text { intake of LNED foods (school } \\
\text { 1: PE 0.88; SE 0.41*; school 2: } \\
\text { PE 1.07; SE } 0.46^{*} \text { ) }\end{array}$ & Good \\
\hline $\begin{array}{l}\text { Shoham et al., } 2012^{83} \\
\text { Setting: School }\end{array}$ & $\begin{array}{l}\mathrm{N}=1,775 ; 49 \% \text { female; mean } \\
\text { age } 16.1 \text { (SD 1.1) in school 1, } \\
\text { and } 16.5(0.9) \text { in school } 2 \\
\text { Country: USA (using Add } \\
\text { Health data) }\end{array}$ & $\begin{array}{l}\text { In both schools, adolescents } \\
\text { chose friends with similar BMI } \\
\text { (school 1: PE 0.54, CI 0.14 - } \\
0.95 \text {; school 2: PE 1.30, CI } \\
0.68-1.91 \text { ) } \\
\text { In school 1, homophilic social } \\
\text { selection was found for active } \\
\text { sports, adolescents chose } \\
\text { friends who played similar } \\
\text { sports: PE } 0.59 \text {, CI } 0.21-0.96 \text {. } \\
\text { This finding was not significant } \\
\text { in either school when all forms } \\
\text { of PA were included }\end{array}$ & $\begin{array}{l}\text { BMI average similarity score in } \\
\text { school 1: PE } 14.10 \text {, CI } 7.76 \text { - } \\
20.44 \text {. Adolescents are more } \\
\text { likely to try to match the } \\
\text { average BMI of their friends. } \\
\text { Adolescents were likely to be } \\
\text { influenced by extremes of peer } \\
\text { behavior, to change their screen } \\
\text { time behavior and playing } \\
\text { active sport behavior to match } \\
\text { their friends (can increase or } \\
\text { decrease the behavior } \\
\text { dependent on friends' behavior) }\end{array}$ & Good \\
\hline
\end{tabular}

$\wedge$ Italic script indicates missing information or non-significant findings 
+ ve: Study showed positive and statistically significant association

AOR: Adjusted Odds Ratio; BMI; Body Mass Index; CI: Confidence Interval; coef: coefficient; LNED: low-nutrient energy-dense; NS: Non-Significant at 5\% significance level; OR: Odds Ratio; PE: Parameter Estimate; r: correlation between predicted and observed values of y in a regression analyses; SD:

Standard Deviation; SE: Standard Error; TP: Time-Point, $x^{2}$ : Fishers combination test

(5) Unilateral friend indicates the friendship is non-reciprocated (it is a one-sided friendship). A reciprocated friendship indicates both members of the friendship tie nominate each other ${ }^{8982}$ 
Table 2: Popularity: engagement in health behavior(s) leading to changes in social status

\begin{tabular}{|c|c|c|c|}
\hline Reference & Study details & Outcome & Study quality \\
\hline \multicolumn{4}{|l|}{ Alcohol drinking } \\
\hline $\begin{array}{l}\text { Cheadle et al., } 2013^{54} \\
\text { Setting: Home and school } \\
\text { Longitudinal }\end{array}$ & $\begin{array}{l}\mathrm{N}=3,561 ; 49 \% \text { female; mean grade } \\
10.27 \text { (age not specified) } \\
\begin{array}{l}\text { Country: USA (using Add Health } \\
\text { data) }\end{array}\end{array}$ & NS association for alcohol use and popularity & Good \\
\hline $\begin{array}{l}\text { Giletta et al., } 2012^{66} \\
\text { Setting: School } \\
\text { Longitudinal }\end{array}$ & $\begin{array}{l}\mathrm{N}=704 ; 47 \% \text { female; mean age } \\
15.53 \text { years ( } S D \text { not reported }) \\
\text { Country: Italy }\end{array}$ & $\begin{array}{l}\text { +ve: Adolescents who drank more alcohol were more } \\
\text { popular (received more friendship nominations: PE } \\
0.11, \text { SE } .02^{* * *} \text { ) }\end{array}$ & Good \\
\hline $\begin{array}{l}\text { Balsa et al., } 2011^{91} \\
\text { Setting: Home and school } \\
\text { Cross-sectional }\end{array}$ & $\begin{array}{l}\mathrm{N}=12,547 ; 52 \% \text { female; mean age } \\
15.7 \text { years (SD } \text { not reported }^{\wedge} \text { ) } \\
\begin{array}{l}\text { Country: USA (using Add Health } \\
\text { data) }\end{array}\end{array}$ & $\begin{array}{l}\text { +ve: If boys' drinking frequency was below } \\
\text { classmates' ave., any alcohol consumption increased } \\
\text { popularity: coef } 3.35^{* *}, \text { SE } 1.05 \text {. NS for girls. 'Getting } \\
\text { drunk' increased boys' popularity further (if the } \\
\text { frequency of getting drunk was below classmates' } \\
\text { ave.) coef } 4.24^{* *}, \text { SE } 1.41 \text {. NS for girls. } \\
\text { NS association with popularity if drinking frequency } \\
\text { or getting drunk are above peer average levels. NS } \\
\text { association in girls. }\end{array}$ & Good \\
\hline $\begin{array}{l}\text { Ali, Amialchuk and Nikaj, 2014 } \\
\text { Setting: Home and school } \\
\text { Cross-sectional }\end{array}$ & $\begin{array}{l}\mathrm{N}=19,871 ; 50.5 \% \text { female; mean } \\
\text { age } 15.17 \text { years (SD not reported) } \\
\begin{array}{l}\text { Country: USA (using Add Health } \\
\text { data) }\end{array}\end{array}$ & $\begin{array}{l}\text { +ve: Any past year individual alcohol consumption } \\
\text { increased popularity (in-degree): PE } 0.47^{* *}, \text { SD } 0.15 \text {. } \\
\text { Greater increase in popularity by being drunk over just } \\
\text { any alcohol consumption: (in-degree) PE } 1.00^{* *}, \mathrm{SD} \\
0.29\end{array}$ & Fair \\
\hline $\begin{array}{l}\text { Gallupe, } 2014^{93} \\
\text { Setting: Home and school } \\
\text { Longitudinal }\end{array}$ & $\begin{array}{l}\mathrm{N}=13,539 ; 51 \% \text { female; mean age } \\
15.82 \text { years (SD } 1.57 \text { ) } \\
\begin{array}{l}\text { Country: USA (using Add Health } \\
\text { data) }\end{array}\end{array}$ & $\begin{array}{l}\text { +ve: Alcohol use was associated with increased } \\
\text { popularity (in-degree) in the low-alcohol group(6) coef } \\
0.08^{* *} \text {, SE } 0.02 \text { but } N S \text { association in the high alcohol } \\
\text { group(6) and popularity }\end{array}$ & Fair \\
\hline
\end{tabular}




\begin{tabular}{|c|c|c|c|}
\hline $\begin{array}{l}\text { Long, Barrett and Lockhart, } 2017^{85} \\
\text { Setting: Home and School } \\
\text { Longitudinal }\end{array}$ & $\begin{array}{l}\mathrm{N}=1,796 ; 47.8 \% \text { female; mean age } \\
16.4 \text { years (SD not reported) } \\
\text { Country: USA (using Add Health } \\
\text { data) }\end{array}$ & NS association between popularity and alcohol use & Poor \\
\hline \multicolumn{4}{|l|}{ Cigarette smoking } \\
\hline $\begin{array}{l}\text { Lakon, Hipp and Timberlake, } 2010^{70} \\
\text { Setting: Home and School } \\
\text { Longitudinal }\end{array}$ & $\begin{array}{l}\mathrm{N}=6,504 ; 38.2 \% \text { female; mean age } \\
14.87 \text { years (SD } 1.73 \text { ) } \\
\begin{array}{l}\text { Country: USA (using Add Health } \\
\text { data) }\end{array}\end{array}$ & $\begin{array}{l}\text { +ve: Smoking was associated with increased } \\
\text { popularity - in-degree centrality increased by } 2.3 \% \text { : } \\
\text { coef } 0.02 * * \text {, SE } 0.01\end{array}$ & Good \\
\hline $\begin{array}{l}\text { Huisman and Bruggeman, } 2012^{79} \\
\text { Setting: School } \\
\text { Longitudinal }\end{array}$ & $\begin{array}{l}\mathrm{N}=961 ; 51.4 \% \text { female; mean age } \\
13.47 \text { years }(\mathrm{SD} 0.6) \\
\text { Country: The Netherlands }\end{array}$ & $\begin{array}{l}\text { +ve: Smoking was associated with increased } \\
\text { popularity - smokers were more likely to receive } \\
\text { friendship nominations: coef } 0.42 * * *\end{array}$ & Poor \\
\hline $\begin{array}{l}\text { Schaefer, Haas and Bishop, } 2012^{90} \\
\text { Setting: Home and School } \\
\text { Longitudinal }\end{array}$ & $\begin{array}{l}\mathrm{N}=509 ; 46.6 \% \text { female; mean age } \\
15.39 \text { years (SD not reported) } \\
\begin{array}{l}\text { Country: USA (using Add Health } \\
\text { data) }\end{array}\end{array}$ & $\begin{array}{l}\text { +ve: Smokers were more popular-study showed a } \\
\text { positive effect for nominating students with higher } \\
\text { levels of smoking as a friend: coef } 0.13^{*}, \text { SE } 0.06\end{array}$ & Poor \\
\hline \multicolumn{4}{|l|}{ Drinking and smoking combined } \\
\hline $\begin{array}{l}\text { Wang et al., } 2016^{73} \\
\text { Setting: Home and School } \\
\text { Longitudinal }\end{array}$ & $\begin{array}{l}\mathrm{N}=2,260 ; 49.9 \% \text { female; mean age } \\
\text { not reported }\left(7^{\text {th }}-12^{\text {th }} \text { grades) }\right. \\
\text { Country: USA (using Add Health } \\
\text { data) }\end{array}$ & $\begin{array}{l}\text { +ve: In the one large school, increased smoking was } \\
\text { associated with being more popular: coef } 0.06^{*}, \mathrm{SE} \\
0.03 \text { (NS in small schools) } \\
\text { +ve: Drinkers were more popular in the small schools } \\
\text { (coef } 0.14^{*} \text {, SE } 0.06 \text { ) compared to larger school (coef } \\
0.40^{*} \text {, SE } 0.02 \text { ) }\end{array}$ & Good \\
\hline \multicolumn{4}{|l|}{ Physical Activity } \\
\hline $\begin{array}{l}\text { Simpkins et al., } 2013^{77} \\
\text { Setting: Home and school } \\
\text { Longitudinal }\end{array}$ & $\begin{array}{l}\mathrm{N}=1,896 ; 46.6 \% \text { female }(\text { school } \mathrm{A}), \\
48.1 \% \text { female (school B), mean age } \\
15.97 \text { years (SD not reported) }\end{array}$ & $\begin{array}{l}\text { +ve: More active adolescents were more popular: coef } \\
-0.02--0.09 \text {; SE } 0.01^{*}-0.02^{* * *} \text { and selected more } \\
\text { friends: coef } 0.06, \text { SE } 0.02^{* * *}\end{array}$ & Good \\
\hline
\end{tabular}




\begin{tabular}{|c|c|c|c|}
\hline & $\begin{array}{l}\text { Country: USA (using Add Health } \\
\text { data) }\end{array}$ & & \\
\hline $\begin{array}{l}\text { De la Haye et al., } 2010^{57} \\
\text { Setting: School } \\
\text { Cross-sectional }\end{array}$ & $\begin{array}{l}\mathrm{N}=385 ; 64 \% \text { female; mean age } 13- \\
14 \text { years (SD not reported) } \\
\text { Country: Australia }\end{array}$ & $\begin{array}{l}\text { Mixed findings: Participation in organized PA was } \\
\text { positively associated with being more popular in } 2 \text { of } 3 \\
\text { male networks PE } 0.17-0.15 \text {, SE } 0.06-0.08(2) \\
\text { NS in female networks }\end{array}$ & Fair \\
\hline \multicolumn{4}{|l|}{ Dietary-related behaviors } \\
\hline $\begin{array}{l}\text { (De la Haye et al., 2013) } \\
\text { Setting: School } \\
\text { Longitudinal }\end{array}$ & $\begin{array}{l}\mathrm{N}=378 ; 46.3 \% \text { female; mean age } \\
13.6 \text { years }(13.6 \text { years (SD 0.4) in } \\
\text { school } 1 \text { and } 13.7 \text { years (SD 0.4) in } \\
\text { school } 2 \text { ) } \\
\text { Country: Australia }\end{array}$ & $\begin{array}{l}+ \text { ve: LNED intake was associated with increasing } \\
\text { popularity in one school, adolescents tended to } \\
\text { befriend friends who had LNED values slightly above } \\
\text { the mean (school } 2 \text { : PE }-0.19 \text {, SE } 0.08^{*} \text { ) more than } \\
\text { peers with low or very high values }\end{array}$ & Good \\
\hline
\end{tabular}

Italic script indicates missing information or non-significant findings

$+v e:$ Study showed positive and statistically significant association

ave: average; coef.: coefficient; LNED: low-nutrient energy-dense; NS: Non-Significant at 5\% significance level; SD: Standard Deviation; SE: Standard Error; PA: Physical Activity; PE: Parameter Estimate

(2) ERGM practice assumes significance if the PE is more than twice it's $S E^{57}$

(6) The low-alcohol group had a mean level of alcohol use of 0.68; high alcohol group had a mean level of alcohol use of 4.42; ranging from 0_never to $6 \_$every day/almost every day ${ }^{93}$ 
Table 3: Popularity: Network popularity predicting health behavior(s)

\begin{tabular}{|c|c|c|c|}
\hline Reference & Study details & Outcome & Study quality \\
\hline \multicolumn{4}{|l|}{ Alcohol drinking } \\
\hline $\begin{array}{l}\text { Gallupe and Bouchard, } 2015^{67} \\
\text { Setting: Home and school } \\
\text { Longitudinal }\end{array}$ & $\begin{array}{l}\mathrm{N}=13,351 ; 50 \% \text { female; mean age } \\
14.75 \text { years (SE } 0.01 \text { ) } \\
\begin{array}{l}\text { Country: USA (using Add Health } \\
\text { data) }\end{array}\end{array}$ & $\begin{array}{l}\text { +ve: More popular adolescents were likely to drink } \\
\text { more alcohol coef } 0.07^{* *} \text {, SE } 0.01\end{array}$ & Good \\
\hline $\begin{array}{l}\text { Lee et al., } 2015^{68} \\
\text { Setting: School } \\
\text { Longitudinal }\end{array}$ & $\begin{array}{l}\mathrm{N}=1,808 ; 53 \% \text { female, (age not } \\
\text { reported) } \\
\text { Country: Northern Taiwan }\end{array}$ & $\begin{array}{l}\text { +ve: Receiving one more peer nomination (in- } \\
\text { degree) was associated with increased occasions of } \\
\text { drinking by } 6 \% \text { aIRR } 1.06,95 \% \text { CI } 1.01-1.10^{*}\end{array}$ & Good \\
\hline $\begin{array}{l}\text { Mundt, Mercken and Zakletskaia, } \\
2012^{84} \\
\text { Setting: Home and school } \\
\text { Longitudinal }\end{array}$ & $\begin{array}{l}\mathrm{N}=2,563 ; 49 \% \text { female; mean age } \\
15.8 \text { years (SD 1.3) } \\
\begin{array}{l}\text { Country: USA (using Add Health } \\
\text { data) }\end{array}\end{array}$ & $\begin{array}{l}\text { +ve: Increase in popularity was associated with } \\
\text { increased alcohol use: coef } 0.08 \text {, SE } 0.02^{*}\end{array}$ & Good \\
\hline $\begin{array}{l}\text { Choukas-Bradley et al., } 2015^{45} \\
\text { Setting: School } \\
\text { Longitudinal }\end{array}$ & $\begin{array}{l}\mathrm{N}=364 ; 53.6 \% \text { female; mean } 15.08 \\
\text { years (SD } 0.55) \\
\text { Country: USA }\end{array}$ & $\begin{array}{l}\text { +ve: Higher levels of popularity were associated } \\
\text { with a higher probability of alcohol use in males (NS } \\
\text { in females) }\end{array}$ & Poor \\
\hline $\begin{array}{l}\text { Fujimoto and Valente, } 2015^{52} \\
\text { Setting: School } \\
\text { Cross-sectional }\end{array}$ & $\begin{array}{l}\mathrm{N}=1,707 ; 52 \% \text { female; mean age } \\
15.07 \text { years (SD } 0.43 \text { ) } \\
\text { Country: USA }\end{array}$ & $\begin{array}{l}\text { +ve: Only in-degree based on perceived popularity } \\
\text { was significantly associated with drinking (AOR } \\
1.35^{* * *}, \mathrm{SE} 0.11 \text { ), } \\
\text { NS association for drinking and in-degree based on } \\
\text { friend nominations }\end{array}$ & Poor \\
\hline \multicolumn{4}{|l|}{ Cigarette smoking } \\
\hline $\begin{array}{l}\text { Alexander et al., } 2001^{55} \\
\text { Setting: Home and School }\end{array}$ & $\begin{array}{l}\mathrm{N}=2525,50 \% \text { female; mean age } \\
15.5 \text { years (SD } 1.5 \text { ) }\end{array}$ & $\begin{array}{l}\text { +ve: Adolescents who had higher levels of } \\
\text { popularity and whose schools had higher smoking }\end{array}$ & Good \\
\hline
\end{tabular}




\begin{tabular}{|c|c|c|c|}
\hline Cross-sectional & $\begin{array}{l}\text { Country: USA (using Add Health } \\
\text { data) }\end{array}$ & $\begin{array}{l}\text { prevalence had a small but increased risk of smoking } \\
\text { (OR } 1.08 * * *, 95 \% \text { CI } 1.01-1.15, \text { SE } 0.04)\end{array}$ & \\
\hline $\begin{array}{l}\text { Robalino and Macy, } 2018^{94} \\
\text { Setting: Home and School } \\
\text { Longitudinal }\end{array}$ & $\begin{array}{l}\mathrm{N}=7,500 ; \\
(\% \text { female \& age not reported }- \text { used } \\
\left.\text { data from Add Health study } y^{43}\right) ; 7^{\text {th }}- \\
12^{\text {th }} \text { grades } \\
\text { Country: USA (using Add Health } \\
\text { data) }\end{array}$ & $\begin{array}{l}\text { +ve: Probability of individual smoking increases } \\
\text { with increasing popularity of peer smokers from } \\
1996-2009 \text { : mean } 0.05^{* * *}-0.03^{* * *} \text {, SE } 0.01- \\
0.01 \text {. The mean popularity of non-smokers decreases } \\
\text { the effect }-0.06^{* * *} \text {, SE } 0.02\end{array}$ & Good \\
\hline $\begin{array}{l}\text { Valente, Fujimoto, Soto et al., } \\
2013^{81} \\
\text { Setting: School } \\
\text { Longitudinal }\end{array}$ & $\begin{array}{l}\mathrm{N}=1,950 ; 58.6 \% \text { female; mean age } \\
14 \text { years (SD not reported) } \\
\text { Country: USA }\end{array}$ & $\begin{array}{l}\text { +ve: Increased popularity was associated with } \\
\text { becoming a smoker AOR } 1.56^{* * *} \text {, SE } 0.25\end{array}$ & Fair \\
\hline $\begin{array}{l}\text { Schaefer, Adams and Haas, } 2013^{56} \\
\text { Setting: Home and School } \\
\text { Longitudinal }\end{array}$ & $\begin{array}{l}\mathrm{N}=509 ; 46.6 \% \text { female; mean age } \\
\text { not reported } \\
\text { Country: USA (using Add Health } \\
\text { data) }\end{array}$ & $\begin{array}{l}\text { +ve: When smokers were popular, increases in peer } \\
\text { influence increased smoking prevalence, but when } \\
\text { they were unpopular, stronger peer influence } \\
\text { decreased smoking prevalence }\end{array}$ & Poor \\
\hline \multicolumn{4}{|l|}{ Substance use } \\
\hline $\begin{array}{l}\text { Kramer and Vaquera, } 2011^{95} \\
\text { Setting: Home and school } \\
\text { Cross-sectional }\end{array}$ & $\begin{array}{l}\mathrm{N}=15,353,51.6 \% \text { female; aged } 12- \\
18 \text { years (SD not reported) } \\
\text { Country: USA (using Add Health } \\
\text { data) }\end{array}$ & $\begin{array}{l}\text { +ve: Compared to socially isolated(7) peers, } \\
\text { individuals who received more friendship } \\
\text { nominations were more likely to drink: OR } 1.66^{* * *} \text {, } \\
\text { SE } 0.14 \text { (compared to socially isolated: } 0.67^{* *}, \mathrm{SE} \\
0.07 \text { ) and binge drink: OR } 1.61^{* * *}, \mathrm{SE} 0.19 \\
\text { (compared to socially isolated: } 0.73^{* *}, \mathrm{SE} 0.09 \text { ) } \\
\text { NS effects for popularity and smoking or marijuana } \\
\text { use }\end{array}$ & Good \\
\hline $\begin{array}{l}\text { Wang et al., } 2018^{76} \\
\text { Setting: Home and School }\end{array}$ & $\begin{array}{l}\mathrm{N}=3,128 \\
(\% \text { female and age not reported) }\end{array}$ & $\begin{array}{l}\text { NS evidence for all } 3 \text { substances that more popular } \\
\text { adolescents were more likely to increase use over } \\
\text { time }\end{array}$ & Good \\
\hline
\end{tabular}




\begin{tabular}{|c|c|c|c|}
\hline Longitudinal & $\begin{array}{l}\text { Country: USA (using Add Health } \\
\text { data) }\end{array}$ & & \\
\hline $\begin{array}{l}\text { Coronges, Stacy and Valente, } 2011^{63} \\
\text { Setting: School } \\
\text { Longitudinal }\end{array}$ & $\begin{array}{l}\mathrm{N}=567,43 \% \text { female; mean age not } \\
\text { reported } \\
\text { Country: USA }\end{array}$ & $\begin{array}{l}\text { NS effect for individual centrality (popularity) and } \\
\text { alcohol or marijuana use }\end{array}$ & Fair \\
\hline $\begin{array}{l}\text { Mathys, Burk and Cillessen, } 2013^{51} \\
\text { Setting: School } \\
\text { Longitudinal }\end{array}$ & $\begin{array}{l}\mathrm{N}=450 ; 53 \% \text { female; mean age } \\
15.5 \text { years (SD not reported) } \\
\text { Country: USA }\end{array}$ & $\begin{array}{l}\text { +ve: Popularity moderated friendship selection based } \\
\text { on alcohol use: PE } 0.12 \text {, SE } 0.04^{* *} \text { - popular } \\
\text { adolescents were more likely to select friends with } \\
\text { high drinking levels } \\
\text { NS effects for popularity moderating marijuana use } \\
\text { or tobacco use }\end{array}$ & Fair \\
\hline $\begin{array}{l}\text { Pearson et al., } 2006^{96} \\
\text { Setting: School } \\
\text { Cross-sectional }\end{array}$ & $\begin{array}{l}\mathrm{N}=3,146 ; 50.3 \% \text { female; aged } 13- \\
15 \text { years (SD not reported) } \\
\text { Country: Scotland }\end{array}$ & $\begin{array}{l}\text { +ve: Drug and alcohol use were more likely in } \\
\text { popular compared to unpopular adolescents (very } \\
\text { popular v unpopular drug use: OR } 1.61^{*} \mathrm{v} 0.56^{* * *} \text {; } \\
\text { very popular v unpopular alcohol use: OR } 1.76^{* * *} \mathrm{v} \\
0.63^{* * *} \text { ) } \\
\text { NS effects for smoking }\end{array}$ & Poor \\
\hline $\begin{array}{l}\text { Moody et al., } 2011^{97} \\
\text { Setting: School } \\
\text { Longitudinal }\end{array}$ & $\begin{array}{l}\mathrm{N}=12,245 ; \% \text { female not stated; } \\
\text { mean age not reported }\left(6^{\text {th }} \& 9^{\text {th }}\right. \\
\text { grade }) \\
\text { Country: USA }\end{array}$ & $\begin{array}{l}\text { +ve: A } 10 \% \text { increase in average popularity increases } \\
\text { substance use (smoking, alcohol, marijuana) by } 0.02 \\
\text { The predicted trajectory slope shows substance use } \\
\text { increases for those adolescents who are at either end } \\
\text { of the popularity scale (strongly increasing or } \\
\text { decreasing popularity levels) }\end{array}$ & Poor \\
\hline
\end{tabular}

$\wedge$ Italic script indicates missing information or non-significant findings

+ve: Study showed positive and statistically significant association 
aIRR: Adjusted Incidence Rate Ratio; AOR: Adjusted Odds Ratio; CI: Confidence Interval; coef: coefficient; NS: Non-Significant at 5\% significance level; PE: parameter estimate; SD: Standard Deviation; SE: Standard Error; OR: Odds Ratio

(7) Kramer and Vaquera (2011) define socially isolated students as receiving no friendship nominations by their class peers, marginally social adolescents as receiving one friendship nomination, and socially saturated adolescents as receiving more than one standard deviation above the mean number of friendship nominations in the class (adolescents who received 9 or more nominations) ${ }^{95}$ 
Table 7: 'Other' network processes and health behaviors

\begin{tabular}{|c|c|c|c|}
\hline Reference & Study details & Outcome & Study quality \\
\hline \multicolumn{4}{|l|}{ Alcohol drinking } \\
\hline $\begin{array}{l}\text { Gallupe and Bouchard, } 2015^{67} \\
\text { Setting: Home and school } \\
\text { Longitudinal }\end{array}$ & $\begin{array}{l}\mathrm{N}=13,351 ; 50 \% \text { female; mean age } \\
14.75 \text { years (SE } 0.01 \text { ) } \\
\text { Country: USA (using Add Health } \\
\text { data) }\end{array}$ & $\begin{array}{l}\text { +ve: Adolescents in denser networks had lower levels } \\
\text { of alcohol use: coef } 0.10^{* *} \text {, SE } 0.01\end{array}$ & Good \\
\hline \multicolumn{4}{|l|}{ Substance use } \\
\hline $\begin{array}{l}\text { Ennett et al., } 2006^{98} \\
\text { Setting: School } \\
\text { Longitudinal }\end{array}$ & $\begin{array}{l}\mathrm{N}=5,104 ; 50.5 \% \text { female; mean age } \\
\text { not reported (equally divided } \\
\text { among } 6^{\text {th }}, 7^{\text {th }} \text { and } 8^{\text {th }} \text { graders) } \\
\text { Country: USA }\end{array}$ & $\begin{array}{l}\text { +ve: Adolescents with higher density networks had } \\
\text { lower odds of recent smoking at age } 15 \text { : OR } 0.92^{* * *} \\
\text { and marijuana use: OR } 0.93^{*} \\
\text { +ve: Social position: isolates were significantly more } \\
\text { likely to report recent smoking than group members, } \\
\text { however growth in alcohol use was less for isolates } \\
\text { than for group members }\end{array}$ & Good \\
\hline
\end{tabular}

${ }^{*} p<0.05,{ }^{* *} p<0.01,{ }^{* * *} p<0.001$

$\wedge$ Italic script indicates missing information

+ve: Study showed positive and statistically significant association

Coef: coefficient; SE: Standard Error; OR: Odds Ratio 
Table 8: Risk of bias and study quality

\begin{tabular}{llllll}
\hline Health behavior & \multicolumn{2}{l}{ Newcastle-Ottawa Scale Risk of Bias } & & $\begin{array}{l}\text { Study } \\
\text { quality }\end{array}$ \\
\hline & Selection & Comparability & Outcome / exposure & Total & \\
\hline Alcohol drinking & & & & & \\
\hline 69 & $* * *$ & $* *$ & $* *$ & 7 & Good \\
\hline 92 & $* *$ & $* *$ & 6 & Fair \\
\hline 91 & $* * *$ & $* *$ & $* *$ & 7 & Good \\
\hline 54 & $* * *$ & $* *$ & $* *$ & 7 & Good \\
\hline 45 & $* * *$ & & $* *$ & 5 & Poor \\
\hline 53 & $* * *$ & $* *$ & $* *$ & 7 & Good \\
\hline 52 & $* *$ & $* *$ & $* *$ & 7 & Fair \\
\hline 67 & $* * *$ & $* *$ & $* *$ & 6 & Food \\
\hline 93 & $* *$ & $* *$ & $* *$ & 6 & Fair \\
\hline 49 & $* *$ & $* *$ & $* *$ & 8 & Good \\
\hline 66 & $* * * *$ & $* *$ & $* *$ & 7 & Good \\
\hline 46 & $* * *$ & $* *$ & $* *$ & 7 & Good \\
\hline 68 & $* * *$ & $* *$ & $* *$ & 5 & Poor \\
\hline 85 & $* * *$ & & $* *$ & 7 & Good \\
\hline 84 & $* * *$ & $* *$ & 5 & Poor \\
\hline 86 & $* *$ & $* *$ & 8 & Good \\
\hline 80 & $* * * *$ & & & \\
\hline & & $* *$ & $* *$ & $7 *$ \\
\hline
\end{tabular}

\section{Cigarette smoking}

\begin{tabular}{|c|c|c|c|c|c|}
\hline 55 & $* * *$ & $* *$ & $* *$ & 7 & Good \\
\hline 65 & $* * *$ & $* *$ & $* *$ & 7 & Good \\
\hline 82 & $* * *$ & & $* *$ & 5 & Poor \\
\hline 87 & $* * *$ & & $* *$ & 5 & Poor \\
\hline 88 & $* * *$ & $* *$ & $* *$ & 7 & Good \\
\hline 79 & $*$ & $* *$ & $* *$ & 5 & Poor \\
\hline 70 & $* * *$ & $*$ & $* *$ & 6 & Good \\
\hline 89 & $* * *$ & $* *$ & $* *$ & 7 & Good \\
\hline 94 & $* * *$ & $* *$ & $* *$ & 7 & Good \\
\hline 90 & $*$ & $* *$ & $* *$ & 5 & Poor \\
\hline 56 & & & $* *$ & 2 & Poor \\
\hline 81 & $* *$ & $* *$ & $* *$ & 6 & Fair \\
\hline
\end{tabular}

Drinking and smoking combined

\begin{tabular}{|c|c|c|c|c|c|}
\hline 62 & $* * *$ & & $* *$ & 5 & Poor \\
\hline 60 & $* * *$ & $* *$ & $* *$ & 7 & Good \\
\hline 71 & $* * *$ & $* *$ & $* *$ & 7 & Good \\
\hline
\end{tabular}




\begin{tabular}{llllll}
\hline 72 & $* * *$ & $* *$ & 5 & Poor \\
\hline 47 & $* *$ & $* *$ & 4 & Poor \\
\hline 61 & $*$ & $* *$ & & 3 & Poor \\
\hline 73 & $* * *$ & $*$ & $* *$ & 6 & Good
\end{tabular}

\begin{tabular}{llllll}
\hline \multicolumn{1}{c}{ Substance use } & & & & \\
\hline 63 & $* *$ & $*$ & $* *$ & 5 & Fair \\
\hline 98 & $* * *$ & $* *$ & $* *$ & 7 & Good \\
\hline 95 & $* * *$ & $* *$ & $* *$ & 7 & Good \\
\hline 51 & $* *$ & $* *$ & $* *$ & 6 & Fair \\
\hline 97 & $* * *$ & $* *$ & 5 & Poor \\
\hline 74 & $* *$ & $* *$ & 4 & Poor \\
\hline 96 & $* * *$ & & 3 & Poor \\
\hline 75 & $*$ & $* *$ & 3 & Poor \\
\hline 48 & $* * *$ & $* *$ & 7 & Good \\
\hline 76 & $* * * *$ & $* *$ & $8 *$ & Good \\
\hline
\end{tabular}

\begin{tabular}{llllll}
\hline \multicolumn{2}{c}{ Physical Activity } & & & & \\
\hline 78 & $* *$ & $* *$ & $* *$ & 6 & Fair \\
\hline 57 & $* *$ & $* *$ & $* *$ & 6 & Fair \\
\hline 39 & $* * *$ & $* *$ & 5 & Poor \\
\hline 58 & $* * *$ & $* *$ & 5 & Poor \\
\hline 77 & $* * *$ & $* *$ & $* *$ & 7 & Good
\end{tabular}

\section{Diet/weight-}

related behaviors

\begin{tabular}{|c|c|c|c|c|c|}
\hline 64 & $* * *$ & $* *$ & $* *$ & 7 & Good \\
\hline 59 & $* * * *$ & $* *$ & $* *$ & 8 & Good \\
\hline 50 & $* * * *$ & $* *$ & $* *$ & 8 & Good \\
\hline 83 & $* * * *$ & $* *$ & $* *$ & 7 & Good \\
\hline
\end{tabular}




\section{References}

1. Kadushin C. Introduction to Social Network Theory. Boston, MA. 2004;

2. Brown BB, Larson J. Peer relationships in adolescents. In: Handbook of Adolescent Psychology Volume 2: Contextual Influences on Adolescent Development. 2009. p. 74-101.

3. Masten CL, Telzer EH, Fuligni AJ, Lieberman MD, Eisenberger NI. Time spent with friends in adolescence relates to less neural sensitivity to later peer rejection. Soc Cogn Affect Neurosci. 2010;7(1):106-14.

4. Rubin KH, Bukowski WM, Parker JG. Peer interactions, relationships, and groups. Handb child Psychol. 1998;

5. Stok FM, de Vet E, de Ridder DTD, de Wit JBF. The potential of peer social norms to shape food intake in adolescents and young adults: a systematic review of effects and moderators. Health Psychol Rev. 2016;10(3):326-40.

6. Fletcher A, Bonell C, Sorhaindo A. You are what your friends eat: Systematic review of social network analyses of young people's eating behaviours and bodyweight. J Epidemiol Community Health [Internet]. 2011;65(6):548-55. Available from: http://queens.ezp1.qub.ac.uk/login?url=http://ovidsp.ovid.com/ovidweb.cgi?T=JS\&CS $\mathrm{C}=\mathrm{Y} \& \mathrm{NEWS}=\mathrm{N} \& \mathrm{PAGE}=$ fulltext $\& \mathrm{D}=\mathrm{psyc} \& \& \mathrm{AN}=2011-11725-010$;

7. MacDonald-Wallis K, Jago R, Sterne JAC. Social network analysis of childhood and youth physical activity: A systematic review. Am J Prev Med [Internet]. 2012;43(6):636-42. Available from: http://dx.doi.org/10.1016/j.amepre.2012.08.021

8. Maturo CC, Cunningham SA. Influence of friends on children's physical activity: a review. Am J Public Health. 2013;103(7):e23-38.

9. Sawka KJ, McCormack GR, Nettel-Aguirre A, Hawe P, Doyle-Baker PK. Friendship networks and physical activity and sedentary behavior among youth: a systematized review. 2013;10(130).

10. Zhang S, de la Haye K, Ji M, An R. Applications of social network analysis to obesity: a systematic review. Obes Rev. 2018;19:976-88.

11. Seo D, Huang Y. Systematic review of social network analysis in adolescent cigarette smoking behavior. J Sch Health. 2012;82(1):21-7.

12. Leung RK, Toumbourou JW, Hemphill SA. The effect of peer influence and selection processes on adolescent alcohol use: a systematic review of longitudinal studies.

Health Psychol Rev. 2014;8(4):426-57. 
13. Kandel DB. Homophily, selection, and socialization in adolescent friendships. Am J Sociol. 1978;84(2):427-36.

14. Mercken L, Steglich C, Sinclair P, Holliday J, Moore L. A longitudinal social network analysis of peer influence, peer selection, and smoking behavior among adolescents in British schools. Heal Psychol. 2012;31(4):450-9.

15. Huang GC, Soto D, Fujimoto K, Valente TW. The interplay of friendship networks and social networking sites: longitudinal analysis of selection and influence effects on adolescent smoking and alcohol use. Am J Public Health. 2014;104(8):e51-9.

16. Harrison K, Bost KK, McBride BA, Donovan SM, Grigsby-Toussaint DS, Kim J, et al. Toward a developmental conceptualization of contributors to overweight and obesity in childhood: The Six-Cs model. Child Dev Perspect. 2011;5(1):50-8.

17. Hawe P, Webster C, Shiell A. A glossary of terms for navigating the field of social network analysis. J Epidemiol Community Health. 2004 Dec;58(12):971-5.

18. Valente TW, Unger JB, Johnson CA. Do popular students smoke? The association between popularity and smoking among middle school students. J Adolesc Heal. 2005;37(4):323-329 7p.

19. Copeland M, Bartlett B, Fisher JC. Dynamic associations of network isolation and smoking behavior. Netw Sci [Internet]. 2017/04/20. 2017;5(3):257-77. Available from: https://www.cambridge.org/core/article/dynamic-associations-of-networkisolation-and-smoking-behavior/0C7822D3FF8DA72F6E3EC65FB18E748B

20. Brechwald WA, Prinstein MJ. Beyond homophily: A decade of advances in understanding peer influence processes. J Res Adolesc. 2011;21(1):166-79.

21. Lerman K, Yan X, Wu X-Z. The "Majority Illusion" in Social Networks. PLoS One [Internet]. 2016 Feb 17;11(2):e0147617. Available from: https://doi.org/10.1371/journal.pone.0147617

22. Conry MC, Morgan K, Curry P, McGee H, Harrington J, Ward M, et al. The clustering of health behaviours in Ireland and their relationship with mental health, self-rated health and quality of life. BMC Public Health. 2011;11(1):692.

23. Hale DR, Viner RM. The correlates and course of multiple health risk behaviour in adolescence. BMC Public Health. 2016;16(1):458.

24. Latkin CA, Knowlton AR. Social network assessments and interventions for health behavior change: a critical review. Behav Med. 2015;41(3):90-7.

25. Pudney S. The Road to Ruin? Sequences of Initiation to Drugs and Crime in Britain. Econ J. 2003;113(486):182-98. 
26. Jessor R. Problem Behavior Theory and Adolescent Health The Collected Works of Richard Jessor, Volume 2. 2017.

27. Wiefferink CH, Buijs GJ, Dam G Ten, Peters L, Paulussen TGWM, Hoekstra F. Clustering of Health-Related Behaviors and Their Determinants: Possible Consequences for School Health Interventions. Prev Sci. 2006;7(2):127-49.

28. Hair EC, Park MJ, Ling TJ, Moore KA. Risky Behaviors in Late Adolescence: Cooccurrence, Predictors, and Consequences. J Adolesc Heal [Internet]. 2009;45(3):25361. Available from: http://dx.doi.org/10.1016/j.jadohealth.2009.02.009

29. Tome G, Matos M, Simoes C, Diniz JA, Camacho I. How can peer group influence the behavior of adolescents: explanatory model. Glob J Health Sci. 2012 Feb;4(2):26-35.

30. Eisenberg ME, Toumbourou JW, Catalano RF, Hemphill SA. Social Norms in the Development of Adolescent Substance Use: A Longitudinal Analysis of the International Youth Development Study. J Youth Adolesc. 2014;43(9):1486-97.

31. Sallis JF, Owen N, Fisher E. Ecological models of health behavior. Heal Behav Theory, Res Pract. 2015;5:43-64.

32. Berkman LF, Glass T. Social Integration, Social Networks, Social Support, and Health. In: Social Epidemiology. 2000. p. 137-73.

33. Webel AR, Okonsky J, Trompeta J, Holzemer WL. A Systematic Review of the Effectiveness of Peer-Based Interventions on Health-Related Behaviors in Adults. Am J Public Health [Internet]. 2010 Feb 1;100(2):247-53. Available from: https://doi.org/10.2105/AJPH.2008.149419

34. Laird Y, Fawkner S, Niven A. A grounded theory of how social support influences physical activity in adolescent girls. Int J Qual Stud Health Well-being. 2018;13(1):1435099.

35. Mendonça G, Cheng LA, Mélo EN, de Farias Júnior JC. Physical activity and social support in adolescents: a systematic review. Health Educ Res. 2014;29(5):822-39.

36. Spencer RA, Rehman L, Kirk SFL. Understanding gender norms, nutrition, and physical activity in adolescent girls: a scoping review. Int $\mathbf{J}$ Behav Nutr Phys Act [Internet]. 2015 Jan 24;12:6. Available from: https://www.ncbi.nlm.nih.gov/pubmed/25616739

37. Draper CE, Grobler L, Micklesfield LK, Norris SA. Impact of social norms and social support on diet, physical activity and sedentary behaviour of adolescents: a scoping review. Child Care Health Dev [Internet]. 2015 Sep 1;41(5):654-67. Available from: https://doi.org/10.1111/cch.12241 
38. Fu L, Jacobs MA, Brookover J, Valente TW, Cobb NK, Graham AL. An exploration of the Facebook social networks of smokers and non-smokers. PLoS One. 2017;12(11):1-15.

39. Lopes V, Gabbard C, Rodrigues LP. Physical Activity in Adolescents: Examining Influence of the Best Friend Dyad. J Adolesc Heal [Internet]. 2013;52(6):752-756 5p. Available from:

http://search.ebscohost.com/login.aspx?direct=true \&db=jlh\&AN=104199739\&site=eh ost-live

40. Liberati A, Altman DG, Tetzlaff J, Mulrow C, Gøtzsche PC, Ioannidis JPA, et al. The PRISMA statement for reporting systematic reviews and meta-analyses of studies that evaluate health care interventions: explanation and elaboration. PLoS Med. 2009;6(7):e1000100.

41. Wells GA, Shea B, O'connell D, Peterson J, Welch V, Losos M, et al. The NewcastleOttawa Scale (NOS) for assessing the quality of nonrandomised studies in metaanalyses. Ottawa (ON): Ottawa Hospital Research Institute; 2009. Available in March. 2016;

42. Likis FE, Andrews JC, Collins MR, Lewis RM, Seroogy JJ, Starr SA, et al. Nitrous oxide for the management of labor pain: a systematic review. Anesth Analg. 2014;118(1):153-67.

43. Harris K, Halpern C, Whitsel E, Hussey J, Tabor J, Entzel P, et al. The National Longitudinal Study of Adolescent to Adult Health: research design [Internet]. Add Health: The National Longitudinal Study of Adolescent to Adult Health. 2009 [cited 2018 Oct 8]. Available from: https://www.cpc.unc.edu/projects/addhealth/design

44. Bidart C, Charbonneau J. How to Generate Personal Networks : Issues and Tools for a Sociological Perspective. Field methods. 2012;23(3):266-86.

45. Choukas-Bradley S, Giletta M, Neblett EW, Prinstein MJ. Ethnic differences in associations among popularity, likability, and trajectories of adolescents' alcohol use and frequency. Child Dev [Internet]. 2015 Mar;86(2):519-535 17p. Available from: http://search.ebscohost.com/login.aspx?direct=true\&db=jlh\&AN=109714730\&site=eh ost-live

46. Kreager DA, Haynie DL. Dangerous liaisons? Dating and drinking diffusion in adolescent peer networks. Am Sociol Rev [Internet]. 2011;76(5):737-63. Available from: http://linksource.ebsco.com.queens.ezp1.qub.ac.uk/linking.aspx?sid=ProQ\%253Aibsss 
hell\&fmt $=$ journal\&genre $=$ article $\&$ issn $=00031224 \&$ volume $=76 \&$ issue $=5 \&$ date $=2011$ $10-$

$01 \&$ spage $=737 \&$ title $=$ American + sociological + review $\&$ atitle $=$ Dangerous + liaisons $\% 25$ $3 \mathrm{~F}+$ Dating+and + drinking

47. Kreager DA, Haynie DL, Hopfer S. Dating and substance use in adolescent peer networks: a replication and extension. Addiction [Internet]. 2013;108(3):638-47. Available from:

http://linksource.ebsco.com.queens.ezp1.qub.ac.uk/linking.aspx?sid=ProQ\%253Aibsss hell\&fmt $=$ journal\&genre $=$ article $\&$ issn $=09652140 \&$ volume $=108 \&$ issue $=3 \&$ date $=2013$ $-03-$

$01 \&$ spage $=638 \&$ title $=$ Addiction $\&$ atitle $=$ Dating + and + substance + use + in + adolescent $+p$ eer + networks $\% 253 \mathrm{~A}+\mathrm{a}+\mathrm{r}$

48. Valente TW, Ritt-Olson A, Stacy A, Unger JB, Okamoto J, Sussman S. Peer acceleration: effects of a social network tailored substance abuse prevention program among high-risk adolescents. Addiction [Internet]. 2007 Nov;102(11):1804-15. Available from:

http://queens.ezp1.qub.ac.uk/login?url=http://ovidsp.ovid.com/ovidweb.cgi?T=JS\&CS $\mathrm{C}=\mathrm{Y} \& \mathrm{NEWS}=\mathrm{N} \& \mathrm{PAGE}=$ fulltext $\& \mathrm{D}=$ med5\&AN $=17784893$

49. Gaughan M. The Gender Structure of Adolescent Peer Influence on Drinking. J Health Soc Behav [Internet]. 2006 Jan;47(1):47-61. Available from:

http://search.ebscohost.com/login.aspx?direct=true\&db=eric\&AN=EJ977084\&site=eh ost-live

50. De la Haye K, Robins G, Mohr P, Wilson C. Adolescents' intake of junk food: Processes and mechanisms driving consumption similarities among friends. J Res Adolesc. 2013;23(3):524-36.

51. Mathys C, Burk WJ, Cillessen AHN. Popularity as a moderator of peer selection and socialization of adolescent alcohol, marijuana, and tobacco use. J Res Adolesc [Internet]. 2013;23(3):513-23. Available from: http://queens.ezp1.qub.ac.uk/login?url=http://ovidsp.ovid.com/ovidweb.cgi?T=JS\&CS $\mathrm{C}=\mathrm{Y} \& N E W S=\mathrm{N} \& \mathrm{PAGE}=$ fulltext $\& \mathrm{D}=\mathrm{psyc} 10 \& \mathrm{AN}=2013-30037-010$

52. Fujimoto K, Valente TW. Multiplex congruity: friendship networks and perceived popularity as correlates of adolescent alcohol use. Soc Sci Med [Internet]. 2015;125:173-81. Available from: http://linksource.ebsco.com.queens.ezp1.qub.ac.uk/linking.aspx?sid=ProQ\%253Aibsss 
hell\&fmt $=$ journal\&genre $=$ article $\&$ issn $=02779536 \&$ volume $=125 \&$ issue $=\&$ date $=2015$ $01-$

$01 \&$ spage $=173 \&$ title $=$ Social + science + and + medicine $\&$ atitle $=$ Multiplex + congruity $\% 25$ $3 \mathrm{~A}+$ friendship+networks

53. Crosnoe R, Muller C, Frank K. Peer context and the consequences of adolescent drinking. Soc Probl [Internet]. 2004;51(2):288-304. Available from:

http://linksource.ebsco.com.queens.ezp1.qub.ac.uk/linking.aspx?sid=ProQ\%253Aibsss hell\&fmt $=$ journal\&genre $=$ article $\&$ issn $=00377791 \&$ volume $=51 \&$ issue $=2 \&$ date $=2004-$ $05-$

$01 \&$ spage $=288 \&$ title $=$ Social + problems $\&$ atitle $=$ Peer + context + and + the + consequences + of+adolescent+drinking

54. Cheadle JE, Stevens M, Williams DT, Goosby BJ. The differential contributions of teen drinking homophily to new and existing friendships: an empirical assessment of assortative and proximity selection mechanisms. Soc Sci Res [Internet]. 2013;42(5):1297-310. Available from:

http://linksource.ebsco.com.queens.ezp1.qub.ac.uk/linking.aspx?sid=ProQ\%253Aibsss hell\&fmt $=$ journal\&genre $=$ article $\&$ issn $=0049089$ X $\&$ volume $=42 \&$ issue $=5 \&$ date $=2013$ $09-$

$01 \&$ spage $=1297 \&$ title $=$ Social + science + research $\&$ atitle $=$ The + differential + contribution $\mathrm{s}+\mathrm{of}+$ teen + drinking

55. Alexander C, Piazza M, Mekos D, Valente T. Peers, schools, and adolescent cigarette smoking. J Adolesc Heal [Internet]. 2001;22-30 9p. Available from: http://search.ebscohost.com/login.aspx?direct=true \&db=jlh\&AN=106911104\&site=eh ost-live

56. Schaefer DR, Adams J, Haas SA. Social Networks and Smoking: Exploring the Effects of Peer Influence and Smoker Popularity through Simulations. Heal Educ Behav [Internet]. 2013 Jan;40(1):24S-32S. Available from:

http://search.ebscohost.com/login.aspx?direct=true \&db=eric\&AN=EJ1019652\&site=e host-live

57. de la Haye K, Robins G, Mohr P, Wilson C. Obesity-related behaviors in adolescent friendship networks. Soc Networks [Internet]. 2010;32(3):161-7. Available from: http://linksource.ebsco.com.queens.ezp1.qub.ac.uk/linking.aspx?sid=ProQ\%253Aibsss hell $\& \mathrm{fmt}=$ journal $\&$ genre $=$ article $\&$ issn $=03788733 \&$ volume $=32 \&$ issue $=3 \&$ date $=2010$ 07-01\&spage $=161 \&$ title $=$ Social + networks\&atitle $=$ Obesity- 
related+behaviors + in + adolescent + friendship + netwo

58. Schofield L, Mummery WK, Schofield G, Hopkins W. The Association of Objectively Determined Physical Activity Behavior among Adolescent Female Friends. Res Q Exerc Sport [Internet]. 2007 Jan;78(2):9-15. Available from:

$\mathrm{http}: / /$ search.ebscohost.com/login.aspx?direct=true\&db=eric\&AN=EJ847340\&site=eh ost-live

59. Bruening M, Eisenberg M, MacLehose R, Nanney MS, Story M, Neumark-Sztainer D. Relationship between Adolescents' and Their Friends' Eating Behaviors: Breakfast, Fruit, Vegetable, Whole-Grain, and Dairy Intake. J Acad Nutr Diet [Internet]. 2012;112(10):1608-1613 6p. Available from:

http://search.ebscohost.com/login.aspx?direct=true\&db=jlh\&AN=104371947\&site=eh ost-live

60. Fujimoto K, Valente TW. Social network influences on adolescent substance use: disentangling structural equivalence from cohesion. Soc Sci Med [Internet]. 2012;74(12):1952-60. Available from:

http://linksource.ebsco.com.queens.ezp1.qub.ac.uk/linking.aspx?sid=ProQ\%253Aibsss hell $\& \mathrm{fmt}=$ journal $\&$ genre $=$ article $\&$ issn $=02779536 \&$ volume $=74 \&$ issue $=12 \&$ date $=2012$ $-06-$

$01 \&$ spage $=1952 \&$ title $=$ Social + science + and + medicine $\&$ atitle $=$ Social + network + influen ces + on + adolescent + su

61. Urberg KA, Degirmencioglu SM, Pilgrim C. Close friend and group influence on adolescent cigarette smoking and alcohol use. Dev Psychol [Internet]. 1997;33(5):83444. Available from:

http:/queens.ezp1.qub.ac.uk/login?url=http://ovidsp.ovid.com/ovidweb.cgi?T=JS\&CS $\mathrm{C}=\mathrm{Y} \& \mathrm{NEWS}=\mathrm{N} \& \mathrm{PAGE}=$ fulltext $\& \mathrm{D}=\mathrm{psyc} 3 \& \mathrm{AN}=1998-00632-010$

62. French DC, Purwono U, Rodkin P. Indonesian Muslim Adolescents' Use of Tobacco and Alcohol: Associations with Use by Friends and Network Affiliates. Merrill-Palmer Q J Dev Psychol [Internet]. 2014 Jan;60(4):385-402. Available from: http://search.ebscohost.com/login.aspx?direct=true\&db=eric\&AN=EJ1046680\&site=e host-live

63. Coronges K, Stacy AW, Valente TW. Social network influences of alcohol and marijuana cognitive associations. Addict Behav [Internet]. 2011;36(12):1305-1308 4p. Available from:

http://search.ebscohost.com/login.aspx?direct=true $\& d b=j l h \& A N=104583614 \&$ site $=$ eh 
ost-live

64. Ali M, Amialchuk A, Gao S, Heiland F. Adolescent weight gain and social networks: is there a contagion effect? Appl Econ [Internet]. 2012;44(23):2969-83. Available from:

http://linksource.ebsco.com.queens.ezp1.qub.ac.uk/linking.aspx?sid=ProQ\%253Aibsss hell\&fmt $=$ journal\&genre $=$ article $\&$ issn $=00036846 \&$ volume $=44 \&$ issue $=23 \&$ date $=2012$ $-08-$

$01 \&$ spage $=2969 \&$ title $=$ Applied + economics $\&$ atitle $=$ Adolescent + weight + gain + and + soc ial+networks $\% 253 \mathrm{~A}+\mathrm{is}+\mathrm{t}$

65. Ali MM, Dwyer DS. Estimating peer effects in adolescent smoking behavior: a longitudinal analysis. J Adolesc Heal [Internet]. 2009;45(4):402-408 7p. Available from:

http://search.ebscohost.com/login.aspx?direct=true\&db=jlh\&AN=105445579\&site=eh ost-live

66. Giletta M, Scholte RHJ, Prinstein MJ, Engels RCME, Rabaglietti E, Burk WJ. Friendship Context Matters: Examining the Domain Specificity of Alcohol and Depression Socialization among Adolescents. J Abnorm Child Psychol [Internet]. 2012 Jan;40(7):1027-43. Available from:

$\mathrm{http}: / /$ search.ebscohost.com/login.aspx?direct=true \&db=eric\&AN=EJ977843\&site=eh ost-live

67. Gallupe O, Bouchard M. The influence of positional and experienced social benefits on the relationship between peers and alcohol use. Ration Soc [Internet].

2015;27(1):40-69. Available from:

http://linksource.ebsco.com.queens.ezp1.qub.ac.uk/linking.aspx?sid=ProQ\%253Aibsss hell\&fmt=journal\&genre $=$ article $\&$ issn $=10434631 \&$ volume $=27 \&$ issue $=1 \&$ date $=2015$ $02-$

$01 \&$ spage $=40 \&$ title $=$ Rationality + and + society $\&$ atitle $=$ The + influence + of + positional + a nd+experienced + socia

68. Lee I-C, Ting T-T, Chen D-R, Tseng F-Y, Chen WJ, Chen C-Y. Peers and social network on alcohol drinking through early adolescence in Taiwan. Drug Alcohol Depend [Internet]. 2015;153:50-58 9p. Available from:

http://search.ebscohost.com/login.aspx?direct=true \&db=jlh\&AN=109604369\&site=eh ost-live

69. Ali MM, Dwyer DS. Social network effects in alcohol consumption among 
adolescents. Addict Behav [Internet]. 2010;35(4):337-342 6p. Available from: $\mathrm{http}: / /$ search.ebscohost.com/login.aspx?direct=true \&db=jlh\&AN=104908527\&site $=$ eh ost-live

70. Lakon CM, Hipp JR, Timberlake DS. The social context of adolescent smoking: a systems perspective. Am J Public Health [Internet]. 2010;100(7):1218-1228 11p. Available from:

http://search.ebscohost.com/login.aspx?direct=true \&db=jlh\&AN=105039152\&site=eh ost-live

71. Fujimoto K, Valente TW. Decomposing the Components of Friendship and Friends' Influence on Adolescent Drinking and Smoking. J Adolesc Heal [Internet] 2012;51(2):136-143 8p. Available from:

http://search.ebscohost.com/login.aspx?direct=true\&db=jlh\&AN=104480503\&site $=$ eh ost-live

72. Kiuru N, Burk WJ, Laursen B, Salmela-Aro K, Nurmi J-E. Pressure to Drink but Not to Smoke: Disentangling Selection and Socialization in Adolescent Peer Networks and Peer Groups. J Adolesc [Internet]. 2010 Jan;33(6):801-12. Available from: http://search.ebscohost.com/login.aspx?direct=true\&db=eric\&AN=EJ904336\&site=eh ost-live

73. Wang C, Hipp JR, Butts CT, Jose R, Lakon CM. Coevolution of adolescent friendship networks and smoking and drinking behaviors with consideration of parental influence. Psychol Addict Behav [Internet]. 2016;30(3):312-24. Available from: http://queens.ezp1.qub.ac.uk/login?url=http://ovidsp.ovid.com/ovidweb.cgi?T=JS\&CS $\mathrm{C}=\mathrm{Y} \& \mathrm{NEWS}=\mathrm{N} \& \mathrm{PAGE}=$ fulltext $\& \mathrm{D}=\operatorname{med} 8 \& \mathrm{AN}=26962975$

74. Pearson M, Steglich C, Snijders T. Homophily and assimilation among sport-active adolescent substance users. Connections. 2006;27(1):47-63.

75. Poulin F, Kiesner J, Pedersen S, Dishion TJ. A Short-Term Longitudinal Analysis of Friendship Selection on Early Adolescent Substance Use. J Adolesc [Internet]. 2011 Jan;34(2):249-56. Available from: http://search.ebscohost.com/login.aspx?direct=true\&db=eric\&AN=EJ916407\&site=eh ost-live

76. Wang C, Hipp J, Butts C, Lakon C. The interdependence of cigarette, alcohol, and marijuana use in the context of school-based social networks. PLoS One [Internet] 2018;13(7) (pagination):Arte Number: e0200904. ate of Pubaton: Juy 2018. Available from: 
http://queens.ezp1.qub.ac.uk/login?url=http://ovidsp.ovid.com/ovidweb.cgi?T=JS\&CS $\mathrm{C}=\mathrm{Y} \& \mathrm{NEWS}=\mathrm{N} \& \mathrm{PAGE}=$ fulltext $\& \mathrm{D}=\mathrm{emexb} \& \mathrm{AN}=623114867$;

77. Simpkins SD, Schaefer DR, Price CD, Vest AE. Adolescent friendships, BMI, and physical activity: Untangling selection and influence through longitudinal social network analysis. J Res Adolesc [Internet]. 2013;23(3):537-49. Available from: http:/queens.ezp1.qub.ac.uk/login?url=http://ovidsp.ovid.com/ovidweb.cgi?T=JS\&CS $\mathrm{C}=\mathrm{Y} \& \mathrm{NEWS}=\mathrm{N} \& \mathrm{PAGE}=$ fulltext $\& \mathrm{D}=\mathrm{psyc} 10 \& \mathrm{AN}=2013-30037-012$

78. de la Haye K, Robins G, Mohr P, Wilson C. How physical activity shapes, and is shaped by, adolescent friendships. Soc Sci Med [Internet]. 2011;73(5):719-28. Available from:

http://linksource.ebsco.com.queens.ezp1.qub.ac.uk/linking.aspx?sid=ProQ\%253Aibsss hell \&fmt $=$ journal\&genre $=$ article $\&$ issn $=02779536 \&$ volume $=73 \&$ issue $=5 \&$ date $=2011$ $09-$

$01 \&$ spage $=719 \&$ title $=$ Social + science + and + medicine $\&$ atitle $=$ How + physical + activity + shapes $\% 252 \mathrm{C}+$ and + is + sha

79. Huisman C, Bruggeman J. The Social Network, Socioeconomic Background, and School Type of Adolescent Smokers. Int J Behav Dev [Internet]. 2012 Jan;36(5):329_ 37. Available from:

http://search.ebscohost.com/login.aspx?direct=true\&db=eric\&AN=EJ990050\&site=eh ost-live

80. Mercken L, Steglich C, Knibbe R, de Vries H. Dynamics of Friendship Networks and Alcohol Use in Early and Mid-Adolescence. J Stud Alcohol Drugs [Internet]. 2012;73(1):99-110. Available from: http://www.jsad.com/doi/10.15288/jsad.2012.73.99

81. Valente TW, Fujimoto K, Soto D, Ritt-Olson A, Unger JB. A Comparison of Peer Influence Measures as Predictors of Smoking Among Predominately Hispanic/Latino High School Adolescents. J Adolesc Heal [Internet]. 2013;52(3):358-364 7p. Available from:

http://search.ebscohost.com/login.aspx?direct=true \&db=jlh\&AN=104241079\&site=eh ost-live

82. Aloise-Young PA, Graham JW, Hansen WB. Peer influence on smoking initiation during early adolescence: a comparison of group members and group outsiders. J Appl Psychol [Internet]. 1994 Apr;79(2):281-7. Available from: http://queens.ezp1.qub.ac.uk/login?url=http://ovidsp.ovid.com/ovidweb.cgi?T=JS\&CS 
$\mathrm{C}=\mathrm{Y} \& \mathrm{NEWS}=\mathrm{N} \& \mathrm{PAGE}=$ fulltext $\& \mathrm{D}=\operatorname{med} 3 \& \mathrm{AN}=8206817$

83. Shoham DA, Tong L, Lamberson PJ, Auchincloss AH, Zhang J, Dugas L, et al. An actor-based model of social network influence on adolescent body size, screen time, and playing sports. PLoS One. 2012;7(6).

84. Mundt MP, Mercken L, Zakletskaia L. Peer selection and influence effects on adolescent alcohol use: a stochastic actor-based model. BMC Pediatr [Internet]. 2012;12:115. Available from:

http:/queens.ezp1.qub.ac.uk/login?url=http://ovidsp.ovid.com/ovidweb.cgi?T=JS\&CS $\mathrm{C}=\mathrm{Y} \& \mathrm{NEWS}=\mathrm{N} \& \mathrm{PAGE}=$ fulltext $\& \mathrm{D}=$ medl $\& \mathrm{AN}=22867027$

85. Long E, Barrett TS, Lockhart G. Network-behavior dynamics of adolescent friendships, alcohol use, and physical activity. Heal Psychol [Internet]. 2017;36(6):577-86. Available from: http://search.ebscohost.com/login.aspx?direct=true \&db=jlh\&AN=123284541\&site=eh ost-live

86. Wang C, Hipp JR, Butts CT, Jose R, Lakon CM. Peer Influence, Peer Selection and Adolescent Alcohol Use: a Simulation Study Using a Dynamic Network Model of Friendship Ties and Alcohol Use. Prev Sci [Internet]. 2017;18(4):382-93. Available from: http://resolver.ebscohost.com/openurl?ctx_ver=Z39.882004\&ctx_enc=info:ofi/enc:UTF8\&rfr_id=info:sid/ProQ\%253Aibss\&rft_val_fmt=info:ofi/fmt:kev:mtx:journal\&rft.gen re $=$ article $\&$ rft.jtitle $=$ Prevention + Science $\&$ rft.atitle $=$ Peer + Influence $\% 252 \mathrm{C}+$ Peer + Selec tion + and $+\mathrm{A}$

87. Go MH, Green Jr HD, Kennedy DP, Pollard M, Tucker JS. Peer influence and selection effects on adolescent smoking. Drug Alcohol Depend [Internet]. 2010;109(13):239-242 4p. Available from:

$\mathrm{http}: / /$ search.ebscohost.com/login.aspx?direct=true $\& \mathrm{db}=\mathrm{jlh} \& \mathrm{AN}=105212629 \&$ site $=\mathrm{eh}$ ost-live

88. Go MH, Tucker JS, Green Jr HD, Pollard M, Kennedy D. Social distance and homophily in adolescent smoking initiation. Drug Alcohol Depend [Internet]. 2012;124(3):347-354 8p. Available from:

http://search.ebscohost.com/login.aspx?direct=true $\& d b=j l h \& A N=104357782 \&$ site $=$ eh ost-live

89. Mercken L, Snijders TAB, Steglich C, Vartiainen E, Vries H de. Dynamics of adolescent friendship networks and smoking behavior. Soc Networks [Internet]. 
2010;32(1):72-81. Available from:

http://linksource.ebsco.com.queens.ezp1.qub.ac.uk/linking.aspx?sid=ProQ\%253Aibsss hell\&fmt=journal\&genre $=$ article $\&$ issn $=03788733 \&$ volume $=32 \&$ issue $=1 \&$ date $=2010$ 01-

$01 \&$ spage $=72 \&$ title $=$ Social + networks $\&$ atitle $=$ Dynamics + of + adolescent + friendship $+n$ etworks+and+smoking + be

90. Schaefer DR, Haas SA, Bishop NJ. A Dynamic Model of US Adolescents' Smoking and Friendship Networks. Am J Public Health [Internet]. 2012;102(6):e12-8 1p. Available from:

http://search.ebscohost.com/login.aspx?direct=true \&db=jlh\&AN=104458140\&site=eh ost-live

91. Balsa AI, Homer JF, French MT, Norton EC. Alcohol use and popularity: Social payoffs from conforming to peers' behavior. J Res Adolesc [Internet]. 2011;21(3):559-68. Available from:

http://queens.ezp1.qub.ac.uk/login?url=http://ovidsp.ovid.com/ovidweb.cgi?T=JS\&CS $\mathrm{C}=\mathrm{Y} \& \mathrm{NEWS}=\mathrm{N} \& \mathrm{PAGE}=$ fulltext $\& \mathrm{D}=\mathrm{psyc} 8 \& A \mathrm{~N}=2011-18074-004$

92. Ali MM, Amialchuk A, Nikaj S. Alcohol consumption and social network ties among adolescents: Evidence from Add Health. Addict Behav [Internet]. 2014;39(5):918-922 5p. Available from:

http://search.ebscohost.com/login.aspx?direct=true $\& d b=j l h \& A N=103816582 \&$ site $=$ eh ost-live

93. Gallupe O. Social status versus coping as motivation for alcohol use. J Youth Stud [Internet]. 2014;17(1):79-91. Available from:

http://linksource.ebsco.com.queens.ezp1.qub.ac.uk/linking.aspx?sid=ProQ\%253Aibsss hell\&fmt=journal\&genre $=$ article $\&$ issn $=13676261 \&$ volume $=17 \&$ issue $=1 \&$ date $=2014$ 01 -

$01 \&$ spage $=79 \&$ title $=$ Journal + of + youth + studies $\&$ atitle $=$ Social + status + versus + coping + as + motivation + for + al

94. Robalino J, Macy M. Peer effects on adolescent smoking: Are popular teens more influential?. PLoS One [Internet]. 2018;13(7). Available from:

http://queens.ezp1.qub.ac.uk/login?url=http://ovidsp.ovid.com/ovidweb.cgi?T=JS\&CS $\mathrm{C}=\mathrm{Y} \& \mathrm{NEWS}=\mathrm{N} \& \mathrm{PAGE}=$ fulltext $\& \mathrm{D}=$ emexa\&AN=622981458;

95. Kramer RA, Vaquera E. Who is really doing it? Peer embeddedness and substance use during adolescence. Sociol Perspect [Internet]. 2011;54(1):37-58. Available from: 
http://linksource.ebsco.com.queens.ezp1.qub.ac.uk/linking.aspx?sid=ProQ\%253Aibsss hell\&fmt=journal\&genre $=$ article $\&$ issn $=07311214 \&$ volume $=54 \&$ issue $=1 \&$ date $=2011$ 04-

01\&spage $=37 \&$ title $=$ Sociological + perspectives $\&$ atitle $=$ Who $+\mathrm{is}+$ really + doing $+\mathrm{it} \% 253$ $\mathrm{F}+\mathrm{Peer}+\mathrm{embeddedness}+\mathrm{a}$

96. Pearson M, Sweeting H, West P, Young R, Gordon J, Turner K. Adolescent substance use in different social and peer contexts: A social network analysis. Drugs Educ Prev policy. 2006;13(6):519-36.

97. Moody J, Brynildsen WD, Osgood DW, Feinberg ME, Gest S. Popularity trajectories and substance use in early adolescence. Soc Networks. 2011;33(2):101-12.

98. Ennett ST, Bauman KE, Hussong A, Faris R, Foshee VA, Cai L, et al. The peer context of adolescent substance use: Findings from social network analysis. J Res Adolesc. 2006;16(2):159-86.

99. Jeon KC, Goodson P. US adolescents' friendship networks and health risk behaviors: a systematic review of studies using social network analysis and Add Health data. PeerJ. 2015;3:e1052.

100. Williams KD, Forgas JP, Hippel W Von. The social outcast: Ostracism, social exclusion, rejection, and bullying. Psychology Press; 2013.

101. Berkman LF, Glass T, Brissette I, Seeman TE. From social integration to health: Durkheim in the new millennium. Soc Sci Med. 2000;51(6):843-57.

102. Hunter R, de la Haye K, Murray J, Badham J, Valente T, Clarke M, et al. Social network interventions for health behaviours and outcomes: A systematic review and meta-analysis. Plos Med. 2019;16(9).

103. Gesell SB, Barkin SL, Valente TW. Social network diagnostics: a tool for monitoring group interventions. Implement Sci. 2013;8(1):116.

104. Hunter RF, McAneney H, Davis M, Tully M, Valente TW, Kee F. "Hidden" social networks in behavior change interventions. J Inf. 2015;105(3).

105. Valente TW. Putting the network in network interventions. Proc Natl Acad Sci. 2017;114(36):9500-1.

106. Kempe D, Kleinberg J, Tardos E. Maximizing the Spread of Influence through a Social Network. 2003;137-46.

107. Valente TW. Network interventions. Science. 2012 Jul;337(6090):49-53.

108. Campbell R, Starkey F, Holliday J, Audrey S, Bloor M, Parry-Langdon N, et al. An informal school-based peer-led intervention for smoking prevention in adolescence 
(ASSIST): a cluster randomised trial. Lancet. 2008;371(9624):1595-602.

109. Hollingworth W, Cohen D, Hawkins J, Hughes RA, Moore LAR, Holliday JC, et al. Reducing smoking in adolescents: cost-effectiveness results from the cluster randomized ASSIST (A Stop Smoking In Schools Trial). Nicotine Tob Res. 2011;14(2):161-8.

110. Sebire SJ, Jago R, Banfield K, Edwards MJ, Campbell R, Kipping R, et al. Results of a feasibility cluster randomised controlled trial of a peer-led school-based intervention to increase the physical activity of adolescent girls (PLAN-A). Int J Behav Nutr Phys Act. 2018;15(1):50.

111. Bell SL, Audrey S, Cooper AR, Noble S, Campbell R. Lessons from a peer-led obesity prevention programme in English schools. Health Promot Int. 2017;32(2):250-9.

112. White J, Hawkins J, Madden K, Grant A, Er V, Angel L, et al. Adapting the ASSIST model of informal peer-led intervention delivery to the Talk to FRANK drug prevention programme in UK secondary schools (ASSIST FRANK): intervention development, refinement and a pilot cluster randomised controlled trial. Public Heal Res. 2017;5(7).

113. Forsyth R, Purcell C, Barry S, Simpson S, Hunter R, McDaid L, et al. Peer-led intervention to prevent and reduce STI transmission and improve sexual health in secondary schools (STASH): protocol for a feasibility study. Pilot Feasibility Stud. 2018;4(1):1-14.

114. Noble N, Paul C, Turon H, Oldmeadow C. Which modifiable health risk behaviours are related? A systematic review of the clustering of Smoking, Nutrition, Alcohol and Physical activity ('SNAP') health risk factors. Prev Med (Baltim). 2015;8:16-41.

115. Meader N, King K, Moe-Byrne T, Wright K, Graham H, Petticrew M, et al. A systematic review on the clustering and co-occurrence of multiple risk behaviours. BMC Public Health [Internet]. 2016;16(1):1-9. Available from: http://dx.doi.org/10.1186/s12889-016-3373-6

116. Pearson N, Biddle SJH, Griffiths P, Johnston JP, Haycraft E. Clustering and correlates of screen-time and eating behaviours among young children. BMC Public Health. 2018;18(1):1-12.

117. Leech RM, McNaughton SA, Timperio A. The clustering of diet, physical activity and sedentary behavior in children and adolescents: A review. Int J Behav Nutr Phys Act [Internet]. 2014;11(1):1-9. Available from: http://www.ijbnpa.org/content/11/1/4\%5Cnhttp://ovidsp.ovid.com/ovidweb.cgi?T=JS 
$\& \mathrm{PAGE}=$ reference $\& \mathrm{D}=$ emed12\&NEWS $=\mathrm{N} \& A \mathrm{~N}=2014073808$

118. Matias TS, Silva KS, Silva JA Da, Mello GT De, Salmon J. Clustering of diet, physical activity and sedentary behavior among Brazilian adolescents in the national school - Based health survey (PeNSE 2015). BMC Public Health. 2018;18(1):1-9.

119. Sekara V, Stopczynski A, Lehmann S. Fundamental structures of dynamic social networks. Proc Natl Acad Sci [Internet]. 2016 Sep 6;113(36):9977-82. Available from: http://arxiv.org/abs/1506.04704\%0Ahttp://dx.doi.org/10.1073/pnas.1602803113

120. Businelle MS, Ma P, Kendzor DE, Frank SG, Vidrine DJ, Wetter DW. An ecological momentary intervention for smoking cessation: Evaluation of feasibility and effectiveness. J Med Internet Res. 2016;18(12):1-14.

121. Dunton GF. Ecological Assessment in Physical Activity Research Genevieve. 2018;45(1):48-54.

122. Heron KE, Everhart RS, McHale SM, Smyth JM. Using Mobile-Technology-Based Ecological Momentary Assessment (EMA) Methods With Youth: A Systematic Review and Recommendations. J Pediatr Psychol. 2017;42(10):1087-107.

123. Stadtfeld C, Snijders TAB, Steglich C, van Duijn M. Statistical Power in Longitudinal Network Studies. Sociol Methods Res [Internet]. 2018 May 1;0049124118769113. Available from: https://doi.org/10.1177/0049124118769113

124. Shah J, P D, N M, Milanaik R. New age technology and social media adolescent psychosocial implications and the need for protective measures. Curr Opin Pediatr. 2019;31(1):148-56.

125. Reid Chassiakos Y (Linda), Radesky J, Christakis D, Moreno MA, Cross C. Children and Adolescents and Digital Media. Pediatrics [Internet]. 2016;138(5):e20162593. Available from: http://pediatrics.aappublications.org/lookup/doi/10.1542/peds.20162593

126. Bandura A. Health promotion by social cognitive means. Heal Educ Behav. 2004;31(2):143-64.

127. Sawyer SM, Afifi RA, Bearinger LH, Blakemore S-J, Dick B, Ezeh AC, et al. Adolescence: a foundation for future health. Vol. 379, The Lancet. 2012. p. 1630-40.

128. Viner RM, Ross D, Hardy R, Kuh D, Power C, Johnson A, et al. Life course epidemiology: recognising the importance of adolescence. J Epidemiol Community Health. 2015 Aug;69(8):719-20.

129. WHO. 1. WHO (2017) Adolescents: health risks and solutions, Available at: http://www.who.int/mediacentre/factsheets/fs345/en/ (Accessed: 9th January 2018). 
Vol. 2018. 2017.

130. Hallal PC, Andersen LB, Bull FC, Guthold R, Haskell W, Ekelund U, et al. Global physical activity levels: surveillance progress, pitfalls, and prospects. Lancet. 2012;380(9838):247-57.

131. Moreno L, Rodriguez G, Fleta J, Bueno-Lozano M, Lazaro A, Bueno G. Trends of dietary habits in adolescents. Crit Rev Food Sci Nutr. 2010;50(2):106-12.

132. Simmonds M, Llewellyn A, Owen CG, Woolacott N. Predicting adult obesity from childhood obesity: A systematic review and meta-analysis. Obes Rev. 2016;17(2):95107.

133. Reinehr T. Long-term effects of adolescent obesity: time to act. Nat Rev Endocrinol [Internet]. 2017 Nov 24;14:183. Available from: https://doi.org/10.1038/nrendo.2017.147

134. Wu XY, Kirk SFL, Ohinmaa A, Veugelers PJ. The importance of health behaviours in childhood for the development of internalizing disorders during adolescence. BMC Psychol. 2017;5(1):38.

135. Scott J. Social network analysis. Sage; 2017. 